\title{
Impacts of transported background ozone on California air quality during the ARCTAS-CARB period - a multi-scale modeling study
}

\author{
M. Huang ${ }^{1}$, G. R. Carmichael ${ }^{1}$, B. Adhikary ${ }^{1,2}$, S. N. Spak ${ }^{1}$, S. Kulkarni ${ }^{1}$, Y. F. Cheng ${ }^{1}$, C. Wei ${ }^{1}$, Y. Tang $^{3}$, \\ D. D. Parrish ${ }^{4}$, S. J. Oltmans ${ }^{4}$, A. D'Allura ${ }^{5}$, A. Kaduwela ${ }^{6}$, C. Cai ${ }^{6}$, A. J. Weinheimer ${ }^{7}$, M. Wong ${ }^{8}$, R. B. Pierce ${ }^{9}$, \\ J. A. Al-Saadi ${ }^{10}$, D. G. Streets ${ }^{11}$, and Q. Zhang ${ }^{11}$ \\ ${ }^{1}$ Center for Global and Regional Environmental Research, the University of Iowa, Iowa City, IA, USA \\ ${ }^{2}$ Kathmandu University, Dhulikhel, Nepal \\ ${ }^{3}$ Meso-scale modeling, NOAA/NCEP/EMC, W/NP2, NOAA, Camp Springs, MD, USA \\ ${ }^{4}$ NOAA/ESRL, Boulder, CO, USA \\ ${ }^{5}$ ARIANET Srl, Milano, Italy \\ ${ }^{6}$ California Air Resource Board, Sacramento, CA, USA \\ ${ }^{7}$ NCAR, Boulder, CO, USA \\ ${ }^{8}$ The University of Maryland, Department of Geography, College Park, MD, USA \\ ${ }^{9}$ NOAA/NESDIS, Madison, WI, USA \\ ${ }^{10}$ NASA Langley Research Center, Hampton, VA, USA \\ ${ }^{11}$ Argonne National Laboratory, Argonne, IL, USA
}

Received: 6 April 2010 - Published in Atmos. Chem. Phys. Discuss.: 10 May 2010

Revised: 19 July 2010 - Accepted: 21 July 2010 - Published: 30 July 2010

\begin{abstract}
Multi-scale tracer and full-chemistry simulations with the STEM atmospheric chemistry model are used to analyze the effects of transported background ozone $\left(\mathrm{O}_{3}\right)$ from the eastern Pacific on California air quality during the ARCTAS-CARB experiment conducted in June, 2008. Previous work has focused on the importance of long-range transport of $\mathrm{O}_{3}$ to North America air quality in springtime. However during this summer experiment the longrange transport of $\mathrm{O}_{3}$ is also shown to be important. Simulated and observed $\mathrm{O}_{3}$ transport patterns from the coast to inland northern California are shown to vary based on meteorological conditions and the $\mathrm{O}_{3}$ profiles over the oceans, which are strongly episodically affected by Asian inflows. Analysis of the correlations of $\mathrm{O}_{3}$ at various altitudes above the coastal site at Trinidad Head and at a downwind surface site in northern California, show that under long-range transport events, high $\mathrm{O}_{3}$ air-masses $\left(\mathrm{O}_{3}>60 \mathrm{ppb}\right)$ at altitudes between about 2 and $4 \mathrm{~km}$ can be transported inland and can
\end{abstract}

significantly influence surface $\mathrm{O}_{3} 20-30 \mathrm{~h}$ later. These results show the importance of characterizing the vertical structure of the lateral boundary conditions (LBC) needed in air quality simulations. The importance of the $\mathrm{LBC}$ on $\mathrm{O}_{3}$ prediction during this period is further studied through a series of sensitivity studies using different forms of LBC. It is shown that the use of the LBC downscaled from RAQMS global model that assimilated MLS and OMI data improves the model performance. We also show that the predictions can be further improved through the use of LBC based on NASA DC-8 airborne observations during the ARCTASCARB experiment. These results indicate the need to develop observational strategies to provide information on the three-dimensional nature of pollutant distributions, in order to improve our capability to predict pollution levels and to better quantify the influence of these Asian inflows on the US west coast air quality. 


\section{Introduction}

Tropospheric ozone $\left(\mathrm{O}_{3}\right)$ is an atmospheric pollutant harmful to human health and agriculture, and is also one of the most important green house gases. The US National Ambient Air Quality Standard (NAAQS) for daily maximum 8-h average $\mathrm{O}_{3}$ has recently been lowered to $75 \mathrm{ppb}$, and is likely to be lowered further to between $60 \mathrm{ppb}$ and $70 \mathrm{ppb}$ in future regulatory reviews of its direct impacts on human health. The California Air Resource Board (CARB) currently sets more stringent state 1-h and 8-h $\mathrm{O}_{3}$ standards at $90 \mathrm{ppb}$ and $70 \mathrm{ppb}$ to better address longstanding urban and regional $\mathrm{O}_{3}$ problems.

The US Environmental Protection Agency (EPA) has defined Policy-Relevant Background $\mathrm{O}_{3}$ (PRB) as those concentrations that would occur in the United States in the absence of anthropogenic emissions in continental North America (EPA, 2006). The PRB concentration defines the level below which national $\mathrm{O}_{3}$ regulatory standards cannot be set. This includes $\mathrm{O}_{3}$ formed through photochemical reactions involving precursors originating exclusively from continental biogenic sources, wildfires, and lightning, as well as $\mathrm{O}_{3}$ transported from outside of North America and from the stratosphere. Current literature indicates an increasing trend of background $\mathrm{O}_{3}$ due to rising global emission trends, and projects that PRB will continue to rise until the end of the 21 st century in North America (Jaffe et al., 2003; Lin et al., 2000; Vingarzan et al., 2004). Previous work has reported a wide range of background $\mathrm{O}_{3}$ in the northern hemisphere based on modeling studies and observational analysis, with estimates varying from $15 \mathrm{ppb}$ to $60 \mathrm{ppb}$ (Fiore et al., 2003; Lefohn et al., 2001; Jaffe et al., 2003). Many of these studies have analyzed observations at remote sites to determine the contributions of long-range $\mathrm{O}_{3}$ transport. However, remote sites of interest are not completely devoid of local anthropogenic impacts (Nolle et al., 2001), and thus these analyses must include techniques to exclude the contributions from regionally polluted air-masses. Modeling studies are also often used, but they contain uncertainties due to coarse spatial resolution and quality of inputs (Fiore et al., 2003). While estimates vary due to differences in season, location, elevation, experimental and modeling methods, there is considerable agreement that less than $40 \mathrm{ppb}$ of PRB is due to natural sources in North America, peaking in spring, and 5-15 ppb is due to trans-continental transport of $\mathrm{O}_{3}$ (Fiore et al., 2002; Vingarzan et al., 2004; McKendry et al., 2006).

Transported $\mathrm{O}_{3}$ from outside the continental US, together with locally-formed $\mathrm{O}_{3}$, contributes to the variability in $\mathrm{O}_{3}$ observed at inland sites in California. A recent study has reported an increasing trend in background $\mathrm{O}_{3}$ over the eastern Pacific since the 1980s during springtime, when Asian emissions have their greatest impacts on the western North America (Cooper et al., 2010). Fewer studies have focused on the role of background $\mathrm{O}_{3}$ in the summertime (Fiore et al., 2003; Parrish et al., 2010), a period with the most frequent and intense episodes of $\mathrm{O}_{3}$ pollution, in which the impact of long-range transport is believed to reach its annual minimum.

Based on multi-year observations, Parrish et al. (2010) contend that the observed summertime $\mathrm{O}_{3}$ over northern California is directly proportional to transported background from the eastern Pacific, and estimate a transport time of 20-30 h for coastal $\mathrm{O}_{3}$ at $1-2.5 \mathrm{~km}$ altitude over Trinidad $\mathrm{Head}$ (THD) to impact surface concentrations over inland $\mathrm{O}_{3}$ non-attainment areas. Background $\mathrm{O}_{3}$ in the transported air averaged $58 \mathrm{ppb}$ on the days that $\mathrm{O}_{3}$ exceeded the current $75 \mathrm{ppb}$ NAAQS at one example site, and was occasionally above $75 \mathrm{ppb}$. This summertime study associated transported background concentrations with higher local concentrations in several locations heavily influenced by $\mathrm{O}_{3}$ formed locally from nearby anthropogenic emissions. Oltmans et al. (2008) has found that summertime background $\mathrm{O}_{3}$ levels over the eastern Pacific in southern California are similar to those in northern California. In addition, Parrish et al. (2009) pointed out the potential similarity in transport patterns from coastal to inland areas over northern and southern California. However, the impact of transported background $\mathrm{O}_{3}$ over southern California is more difficult to discern because of the weaker vertical mixing and the higher local production levels.

Assessing the contributions of distant sources on local pollution levels remains a challenging problem and reducing the uncertainty in estimates requires a better understanding of transport patterns that bring together long-range transported air masses and local pollutants (NAS, 2010). Threedimensional chemical transport modeling is an important complement to observation-based approaches and is critical to fully understand the factors responsible for reported longtime trends (Law, 2010), as well as short-term variations in the properties of transported air masses.

This paper investigates the impacts of $\mathrm{O}_{3}$ transported from the eastern Pacific on California air quality using observational data collected during the California portion of the Arctic Research of the Composition of the Troposphere from Aircraft and Satellites (ARCTAS-CARB) experiment. During the time period of this experiment California was strongly influenced by Asian inflows, and research flights were able to study the air mass chemistry over the eastern Pacific and inland over California. These observations are analyzed using results from the STEM regional-scale modeling system, including tracer model and full-chemistry simulations at two horizontal resolutions. Results from the tracer model and back trajectories are employed to determine days during the experiment when California was strongly influenced by Asian inflows. We show the direct and indirect effects of foreign inflows on measurement sites located at THD, in the northern Central Valley, and in southern California. Based on trajectories and $\mathrm{O}_{3}$ concentration correlation analysis, transport times from the coast to the valley and their altitudinal relationships are estimated for the specific time period influenced by Asian inflows and over the entire ARCTASCARB period. The amount of $\mathrm{O}_{3}$ transported into northern 
California from the free troposphere is estimated according to observed $\mathrm{O}_{3}$ vertical profiles and the inferred transported altitudes.

One research flight was designed to measure air over the eastern Pacific under inflow conditions, providing data to help establish better boundary conditions for use in air quality predictions. Additional modeling analysis was done using these data to evaluate the impact of model lateral boundary conditions (LBC) over the eastern Pacific on predicted surface $\mathrm{O}_{3}$ concentrations over California. The implication of these results for observation and model approaches to improve $\mathrm{O}_{3}$ prediction are also discussed.

\section{Methods}

\subsection{Mission introduction and observational data}

ARCTAS-CARB was conducted in June 2008 by the National Aeronautics and Space Administration (NASA). The NASA DC-8 aircraft platform sampled trace gas and aerosol concentrations through four scientific flights over California on $18,20,22$, and 24 June 2008 . One of the mission's scientific objectives was to characterize upwind boundary conditions necessary to model inland $\mathrm{O}_{3}$ (Jacob et al., 2010) and the 22 June flight was designed specifically for this purpose. On this day, the DC- 8 took off from Palmdale, CA, flew over the Pacific Ocean to THD, and then circled back to Palmdale along the coast (Fig. 1c). This flight will be a focus of this paper. In addition to airborne measurements, continuous hourly $\mathrm{O}_{3}$ measurements were made at CARB and Clean Air Status and Trends Network (CASTNET) surface sites (http://www.arb.ca.gov/qaweb/siteinfo.php; http://www.epa. gov/castnet/). Ozone soundings were also launched on 20, 22, 24, and 26 June 2008 at the remote coastal THD site (ftp://ftp.cmdl.noaa.gov/ozwv/ozone/ARCIONS/CARB/).

Within the CARB and CASTNET surface $\mathrm{O}_{3}$ monitoring network, five California sites were selected for the present analysis (Fig. 1c). Three of them are located in California's Central Valley: an isolated rural site, Tuscan Butte (TB), which has the highest $\mathrm{O}_{3}$ design value (i.e., the 3-year average of the fourth highest daily maximum 8-h average $\mathrm{O}_{3}$ mixing ratio) in the Northern Sacramento Valley (Parrish et al., 2010); a suburban site, Walnut Grove Tower (WGT), 20 miles south of Sacramento; and a remote CASTNET site, Lassen Volcanic National Park (LAV), located to the east of valley. The other two are the CASTNET site at Joshua Tree National Monument (JOT) in southern California, chosen to compare with the northern sites, and a background coastal site at THD, selected for identifying the transport patterns from coast to inland. Elevations of these sites are $572 \mathrm{~m}$, $0 \mathrm{~m}, 1756 \mathrm{~m}, 1244 \mathrm{~m}$ and $20 \mathrm{~m}$, respectively.

\subsection{Model and data}

\subsubsection{Model}

In support of the ARCTAS field experiment we operated a regional chemical weather forecasting system. This system was used both in forecast mode to assist in flight planning, and in post-analysis mode for data analysis. The system was designed and used for the ARCTAS-CARB, and polar spring and summer portions of the experiment. In this paper we focus on the period from 18-28 June 2008. The modeling system is based on the Sulfur Transport and dEposition Model (STEM). The STEM model has been used in several past field campaigns (Carmichael et al., 2003; Tang et al., 2004a, b, 2007; Adhikary et al., 2010). The modeling system applied here (D'Allura et al., 2010) includes three components, illustrated in Fig. 1:

1. a hemisphere tracer model to study long range transport of pollutants and dust with $60 \mathrm{~km}$ horizontal resolution and 30 vertical layers to the stratosphere;

2. a continental scale gas-phase and aerosol chemical transport simulation on a subset of the hemispheric grid with a $60 \mathrm{~km}$ horizontal resolution and 18 vertical layers with the same intervals as the tracer model (i.e., the 18 lowest layers);

3. a regional-scale gas-phase and aerosol chemical transport domain centered over California with a $12 \mathrm{~km}$ horizontal resolution and 32 vertical layers at smaller intervals than in 1) and 2).

The northern hemisphere calculation utilized a tagged tracer version of STEM (Tang et al., 2004a). This model calculates a variety of aerosols, as well as several air mass markers. Because of its long atmospheric life-time of 1-2 months, carbon monoxide (CO) is one of the primary tracers used to estimate the contributions of geographic areas to hemispheric-scale transport. For this study, we included CO tracers for eight regions in the hemispheric domain (Fig. 1a): the US mainland, Alaska, Canada, Greenland, Europe, Russia, China and other Asia nations. These tracers are designed to represent primary $\mathrm{CO}$ only. Additional tracer calculations include air mass ages based on various chemical clocks, which represents a combination of transport time, source intensities and diffusion, using emission and decay rates as a proxy, and a variety of aerosols including sulfate, black carbon and dust. Further details of the tracer model can be found in Tang et al. (2004a).

The STEM full-chemistry model calculates chemistry reactions based on SAPRC 99 gaseous chemical mechanism (Carter, 2000), with photolysis rates coupled with the online Tropospheric Ultraviolet-Visible radiation model (TUV) (Madronich, 2002). It also includes a four-bin aerosol module with thermodynamics calculated using the Simulating Composition of Atmospheric Particles at Equilibrium 

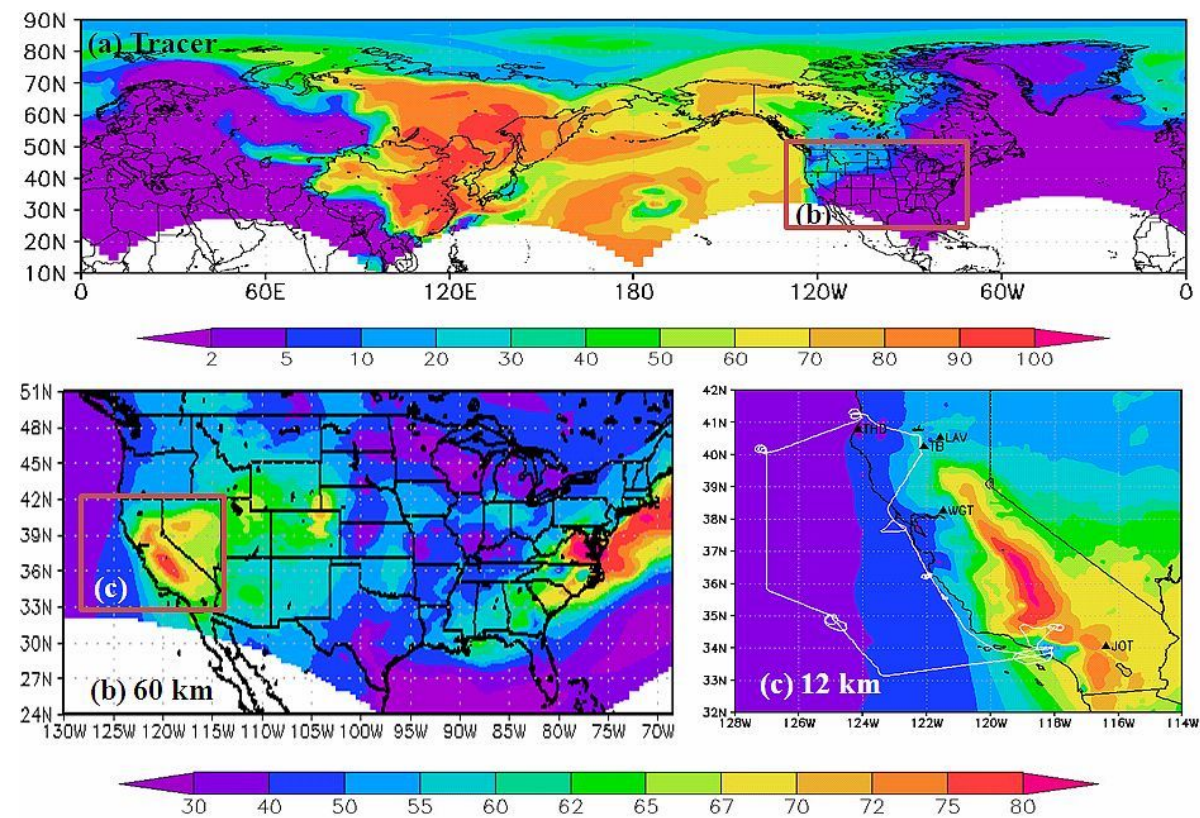

Fig. 1. (a) Averaged (24-h) surface contributions of anthropogenic China CO as \% during 21-24 June in the entire tracer domain; averaged (24-h) $\mathrm{O}_{3}$ concentrations at surface from the (b) $60 \mathrm{~km}$ (partial domain) and (c) $12 \mathrm{~km}$ (entire domain surface sites and $22 \mathrm{June}$ DC-8 flight path included) model simulations during 18-28 June 2008.

(SCAPE II) model (Kim and Seinfeld, 1995). A detailed description of the current STEM-2K3 model can be found in a recent paper by Adhikary et al. (2010). The STEM full-chemistry calculations were performed using $60 \mathrm{~km}$ and $12 \mathrm{~km}$ resolutions in this study and the model setups are summarized in Table 1. The predictions at two different resolutions provide the opportunity to test the sensitivity of regional $\mathrm{O}_{3}$ distributions to model resolution and the treatment of lateral boundary conditions. The $60 \mathrm{~km}$ resolution is representative of that used in more advanced global-scale chemical transport models, while the $12 \mathrm{~km}$ resolution represents a more typical resolution used in regional-scale air quality studies.

\subsubsection{Meteorology}

In this study, meteorology fields for all three grids were generated by the Advanced Research Weather Research \& Forecasting Model (WRF-ARW) Version 2.2.1 (Skamarock et al., 2007) with forecast and reanalyzed meteorological inputs (Mesinger et al., 2006) for the $60 \mathrm{~km}$ and $12 \mathrm{~km}$ simulations, respectively. The $60 \mathrm{~km}$ WRF grid included 30 layers and the $12 \mathrm{~km}$ grid included 40 layers. The tracer model used the simulated meteorological fields from all 30 layers; while the $60 \mathrm{~km}$ and $12 \mathrm{~km}$ full chemistry simulations only used the lowest 18 and 32 layers, respectively. The WRF-ARW simulations at both resolutions utilized the same physics and dynamics schemes. The primary physics options include Goddard shortwave (Chou and Suarez, 1994) and Rapid Radiative Transfer Model (RRTM) long wave scheme (Mlawer et al., 1997), the NOAH land and surface model (Chen and Dudhia, 2001), Monin-Obukhov similarity theory (Monin and Obukhov, 1954) with the Mellor-Yamada-Janjic planetary boundary layer closure scheme (Janjic, 2002), WSM 5class microphysics (Hong et al., 2004) and the Betts-MillerJanjic scheme (Janjic, 2000). The STEM preprocessor was used to extract topography and other land use variables along with the meteorological parameters. Other model inputs, such as emissions, initial and boundary conditions were gridded for the same map projection and grid resolution, which will be discussed in detail in the following sections.

\subsubsection{Emissions}

An ARCTAS-specific emission inventory was developed based on regional-specific information on fuels and activity from various economic sectors to support the field experiment (Streets et al., 2008, http://mic.greenresource.cn/ arctas_premission). For the continental US the ARCTAS emissions inventory includes anthropogenic emissions from the 2001 National Emissions Estimate Version 3, an update of the 1999 US National Emissions Inventory with growth factors applied by Source Classification Code, and augmented with national inventories for Canada (2000) and Mexico (1999). Daily biomass burning emissions from the Real-time Air Quality Modeling System (RAQMS) (Pierce et al., 2007), provided by the Cooperative Institute for Meteorological Satellite Studies (CIMSS) were used. Biogenic emissions of terpene and isoprene were taken from 
Table 1. Summary of STEM inputs for base cases in two resolutions.

\begin{tabular}{|c|c|c|c|c|}
\hline \multirow[t]{2}{*}{ Model Inputs } & \multicolumn{2}{|c|}{ Raw data sources } & \multicolumn{2}{|c|}{ Raw data resolutions } \\
\hline & $\begin{array}{l}60 \mathrm{~km} / 18 \text { layers } / 6 \mathrm{~h} \\
\text { base case }\end{array}$ & $\begin{array}{l}12 \mathrm{~km} / 32 \text { layers } / 1 \mathrm{~h} \\
\text { base case }\end{array}$ & $60 \mathrm{~km}$ & $12 \mathrm{~km}$ \\
\hline $\begin{array}{l}\text { Meteorology, WRF } \\
2.2 .1\end{array}$ & $\begin{array}{l}\text { GFS + one time } \\
\text { step SST }\end{array}$ & NARR + daily SST & $6 \mathrm{~h}, 1^{\circ} \times 1^{\circ}$ & $3 \mathrm{~h}, 36 \mathrm{~km}$ \\
\hline $\begin{array}{l}\text { Anthropogenic } \\
\text { Emissions } \\
\text { (point and } \\
\text { mobile) }\end{array}$ & $\begin{array}{l}\text { NEI 2001, weekday } \\
\text { varied from week- } \\
\text { ends }\end{array}$ & $\begin{array}{l}\text { CARB 2005, pro- } \\
\text { jected from 2002, } \\
\text { daily varied. } \\
\text { Out of CARB } \\
\text { domain filled with } \\
\text { NEI } 2001\end{array}$ & $1^{\circ} \times 1^{\circ}, 1 \mathrm{~h}$ & $4 \mathrm{~km} \times 4 \mathrm{~km}, 1 \mathrm{~h}$ \\
\hline $\begin{array}{l}\text { Biogenic } \\
\text { Emissions }\end{array}$ & Orchidee & $\begin{array}{l}\text { CARB 2005, pro- } \\
\text { jected from 2002, } \\
\text { daily varied }\end{array}$ & $\begin{array}{l}1^{\circ} \times 1^{\circ} \\
\text { monthly averaged }\end{array}$ & $4 \mathrm{~km} \times 4 \mathrm{~km}, 1 \mathrm{~h}$ \\
\hline $\begin{array}{l}\text { Biomass bur- } \\
\text { ning Emissions }\end{array}$ & RAQMS real time & $\begin{array}{l}\text { MODIS-detected } \\
\text { hot spots being } \\
\text { processed by the } \\
\text { prep-chem-source } \\
\text { model, mass- } \\
\text { conserved normal- } \\
\text { ization }\end{array}$ & $1^{\circ} \times 1^{\circ}, 12 \mathrm{~h}$ & $1 \mathrm{~km} \times 1 \mathrm{~km}, 24 \mathrm{~h}$ \\
\hline $\begin{array}{l}\text { Top and Lateral } \\
\text { Boundary } \\
\text { Conditions }\end{array}$ & $\begin{array}{l}\text { RAQMS real time } \\
\text { (gases) }+ \text { STEM } \\
\text { tracer } \\
\text { aerosols) }\end{array}$ & $\begin{array}{l}\text { STEM } 60 \mathrm{~km} \text { base } \\
\text { case }\end{array}$ & $\begin{array}{l}2^{\circ} \times 2^{\circ}, 6 \mathrm{~h} \& \\
60 \mathrm{~km} \times 60 \mathrm{~km}, \\
6 \mathrm{~h}\end{array}$ & $\begin{array}{l}60 \mathrm{~km} \times 60 \mathrm{~km}, \\
18 \text { layers, } 6 \mathrm{hrs}\end{array}$ \\
\hline $\begin{array}{l}\text { Ozone column, re- } \\
\text { quired by the TUV } \\
\text { model }\end{array}$ & $\begin{array}{l}\text { Measured by Ozone } \\
\text { trometer (OMI) instrui } \\
\text { NASA Aura spacecraf }\end{array}$ & $\begin{array}{l}\text { Mapping Spec- } \\
\text { ment on board the } \\
\mathrm{ft} \text {, daily }\end{array}$ & $1^{\circ} \times 1^{\circ}, 1$ day & \\
\hline
\end{tabular}

twelve-year-averaged data from the Orchidee model (Lathiere et al., 2006).

For the analysis of the ARCTAS-CARB portion of the experiment discussed in this paper we performed additional simulations at $12 \mathrm{~km}$ using anthropogenic and biogenic emissions re-gridded from a contemporary CARB $4 \mathrm{~km}$ emission inventory. Biomass burning emissions were generated by the prep-chem-source model (WRF/Chem Version 3.1 users' guide, 2009), which used the MODIS - detected point fire information at $1 \mathrm{~km}$ ground resolution (Davies et al., 2009; Giglio et al., 2003) and was adjusted at each time step to match total emissions rates from RAQMS.

\subsubsection{Lateral boundary conditions}

Lateral boundary conditions are a significant source of uncertainties in the predictions of regional air quality. Traditionally they have been set at constant values based on available climatological information. In a previous study we have shown that the use of temporal and spatial variations in top and lateral boundary conditions downscaled from global models can enhance model performance, especially for longlive species and over areas less impacted by local pollution (Tang et al., 2007). In a follow-on study Tang et al. (2009) also concluded that the use of global model predictions for LBC improved the correlation coefficients of surface $\mathrm{O}_{3}$ prediction over the U.S. west coast. However, the global model boundary conditions also contain large uncertainties, which get transferred into the regional models. For example Tang et al. (2009) found for the US that the use of global model boundary conditions, while improving many aspects of the predictions may also increase the $\mathrm{O}_{3}$ mean bias. Thus there is a need to continue to develop methods that can improve the quality of the boundary conditions. In this paper we explore further the sensitivity of regional models to a variety of western LBCs (Table 2). 
Table 2. Summary of STEM lateral boundary condition sensitivity studies.

\begin{tabular}{|c|c|c|c|}
\hline Name & Descriptions & $\begin{array}{l}\text { Resolut } \\
\text { applied } \\
60 \mathrm{~km}\end{array}$ & $12 \mathrm{~km}$ \\
\hline $\begin{array}{l}\text { Clean Western Bound- } \\
\text { ary Conditions (Clean } \\
\text { WBC) }\end{array}$ & $\begin{array}{l}\text { Constant } 40 \mathrm{ppb} \mathrm{O}_{3}, 90 \mathrm{ppb} \mathrm{CO} \\
\text { as western } \mathrm{LBC}\end{array}$ & $\checkmark$ & \\
\hline $\begin{array}{l}\text { Fixed RAQMS Bound- } \\
\text { ary Conditions (Fixed } \\
\text { BC) }\end{array}$ & $\begin{array}{l}\text { Temporally fix top BC and } \\
\text { LBCs for all species using av- } \\
\text { eraged 20-day BCs in the base } \\
\text { case }\end{array}$ & $\checkmark$ & \\
\hline $\begin{array}{l}\text { Reduced Western } \\
\text { Boundary Conditions } \\
\text { (Reduced WBC) }\end{array}$ & $\begin{array}{l}\text { Reduce } 10 \mathrm{ppb} \text { of } \mathrm{O}_{3} \text { from the } \\
\text { western } \mathrm{LBC} \text { in the Fixed } \mathrm{BC} \\
\text { case }\end{array}$ & $\checkmark$ & \\
\hline $\begin{array}{l}\text { Observational-based } \\
\text { Western Boundary } \\
\text { Conditions (Obs. } \\
\text { cases) }\end{array}$ & $\begin{array}{l}\text { Measurements on the June } 22 \\
\text { DC- } 8 \text { flight were interpolated to } \\
\text { STEM grids as western LBC } \\
\text { for the flight week, species in- } \\
\text { cluded: } \mathrm{NO}_{x}, \mathrm{CO}, \mathrm{O}_{3}, \mathrm{H}_{2} \mathrm{O}_{2} \text {, } \\
\text { PAN, } \mathrm{HNO}_{3}, \mathrm{SO}_{2}\end{array}$ & $\checkmark$ & $\checkmark$ \\
\hline
\end{tabular}

In the base simulation for the $60 \mathrm{~km}$ domain the $\mathrm{LBC}$ for thirty gaseous species, and the top boundary conditions for ten gaseous species (not listed) were taken from the archived RAQMS real-time chemical analyses data with a 6 hour resolution. RAQMS real-time chemical analyses included assimilation of stratospheric (above $250 \mathrm{mb}$ ) $\mathrm{O}_{3}$ profiles from the Microwave Limb Sounder (MLS) and cloud cleared total $\mathrm{O}_{3}$ columns from the $\mathrm{O}_{3}$ Monitoring Instrument (OMI) onboard the NASA Aura satellite. The RAQMS $\mathrm{O}_{3}$ profiles were compared with measurements by Tropospheric Emission Spectrometer (TES) onboard the NASA Aura satellite for Step and Stare observations over the Eastern Pacific $\left(150^{\circ} \mathrm{E}-120^{\circ} \mathrm{E}, 30^{\circ} \mathrm{N}-60^{\circ} \mathrm{N}\right)$ during 15 June-15 July. RAQMS mean biases relative to TES were generally less than $10 \%$, except near $100 \mathrm{mb}$ where the bias was up to $20 \%$ lower than TES. The RMS errors ranged from 20 to $40 \%$ in the troposphere with peaks near $200 \mathrm{mb}$ and below $800 \mathrm{mb}$. RAQMS underestimated tropospheric $\mathrm{O}_{3}$ variability by about $20 \%$ relative to TES. Comparison with ten Trinidad $\mathrm{Head}_{3}$ sondes launched between 27 June and 6 July showed that the RAQMS real-time $\mathrm{O}_{3}$ analysis had a mean high bias in the troposphere (below $200 \mathrm{mb}$ ) which ranged from $10 \%$ below $500 \mathrm{mb}$ to $30 \%$ at $300 \mathrm{mb}$. The $12 \mathrm{~km}$ base case simulation was performed as a one-way nesting within the STEM $60 \mathrm{~km}$ base case. The predictions using the $60 \mathrm{~km}$ resolution were used as boundary conditions for the $12 \mathrm{~km}$ simulations.
Additional simulations were performed in the $60 \mathrm{~km}$ resolution model with various western LBCs to further study the sensitivity of modeled $\mathrm{O}_{3}$ to the western $\mathrm{LBC}$ in the $60 \mathrm{~km}$ model grid. These studies were designed to isolate the impact of the $\mathrm{LBC}$ on the $\mathrm{O}_{3}$ predictions in the outer grid, as it is this information that gets transferred into any inner grids. In the Clean WBC case, $\mathrm{O}_{3}$ and $\mathrm{CO}$ concentrations in the western LBC were set to constants (vertically, horizontally and temporally) at $40 \mathrm{ppb}$ and $90 \mathrm{ppb}$, respectively. This constant $40 \mathrm{ppb}$ background $\mathrm{O}_{3}$ level is often used as a baseline for $\mathrm{O}_{3}$ risk assessments by the US EPA. In the Fixed BC case, temporal variability was eliminated in the top and all LBCs by using 20-day (10 June-30 June 2008) time-averaged RAQMS boundary conditions. In the Reduced WBC case, a systematic bias in ozone was introduced to the Fixed $\mathrm{BC}$ values by reducing $\mathrm{O}_{3}$ by $10 \mathrm{ppb}$ in every grid cell along the western boundary. Finally, in the Obs case, we explore the impact of using the observations on model performance. For this case the observations from the 22 June DC- 8 flight were interpolated to the $60 \mathrm{~km}$ and $12 \mathrm{~km}$ model grid and used directly as the western LBC. Details of the various LBCs used in these studies are summarized in Table 2. 

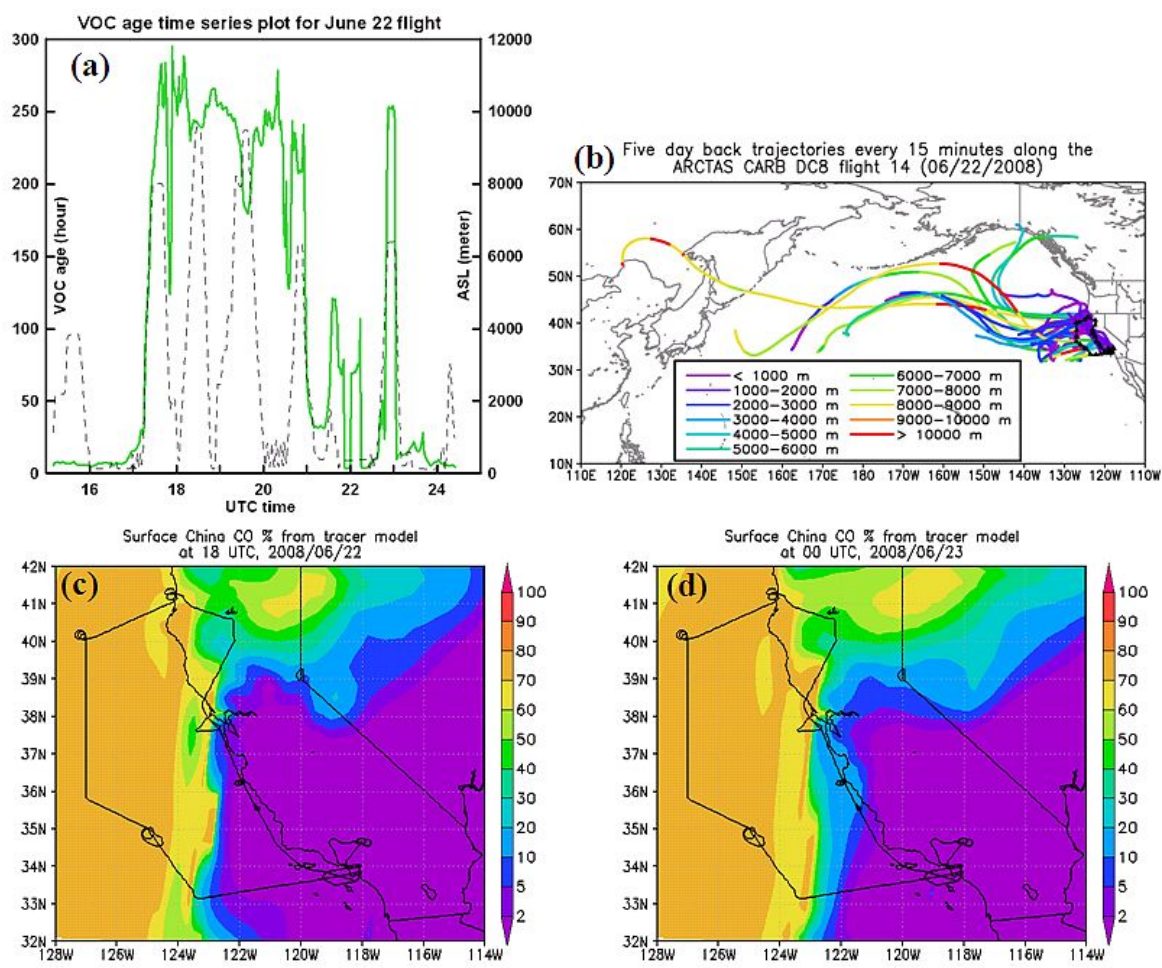

Fig. 2. (a) VOC ages and (b) five-day back trajectories along the 22 June DC- 8 flight path; tracer surface contributions of anthropogenic China CO as \% over California during flight time (c) 18:00 UTC (d) 24:00 UTC (00:00UTC, 23 June).

\section{Results and discussions}

\section{1 $\mathrm{O}_{3}$ concentrations and air-mass movement during ARCTAS-CARB}

The 24-h average surface $\mathrm{O}_{3}$ concentrations during 18-28 June 2008 from the $60 \mathrm{~km}$ and $12 \mathrm{~km}$ base case simulations are shown in Fig. 1b, c, respectively. The entire $12 \mathrm{~km}$ domain is shown but only the US continental portion of the $60 \mathrm{~km}$ domain is included. From the $60 \mathrm{~km}$ case we see that during this period the entire western US had enhanced ozone levels ( $>55 \mathrm{ppbv}$ ), with the highest values in California. From the $12 \mathrm{~km}$ simulations much of California had $\mathrm{O}_{3}$ levels in excess of $70 \mathrm{ppbv}$, with the highest values in the Central Valley and in southern California. The on-shore flow conditions along the eastern Pacific are shown by the strong west to east gradients along the west coast of California. The impact of model resolution on surface $\mathrm{O}_{3}$ is also shown by the sharpness in the gradients and by the differences in the distributions. Horizontally, the increased resolution captured more local features around urban emissions sources and better captured aspects of the wind fields (spatially and temporally) over California (which will be discussed in more detail below). Vertically, the $12 \mathrm{~km}$ simulation produced mixing layer heights closer to those reported in previous studies , especially at valley sites (Dillon et al., 2002), ranging from several hundred meters to $\sim 2000 \mathrm{~m}$ above ground. Temporally, the $12 \mathrm{~km}$ simulations were able to better capture the strong diurnal variations in $\mathrm{O}_{3}$ seen at some of the surface sites (which will be discussed in more details later).

As mentioned earlier, during 21-24 June, Asian inflows entered the west coast of the US. The mean value of the estimate of the impact of China $\mathrm{CO}$ at the surface, calculated using the primary $\mathrm{CO}$ source region tagged tracers, is presented Fig. 1a and expressed in terms of \% of total anthropogenic primary CO. Over the eastern Pacific the China contribution exceeds 50\%, and over Northern California it is greater than $20 \%$. During this period the weather over California was dominated by high pressure centered over the Pacific, with weak mid-latitude cyclonic disturbance (Fuelberg et al., 2010). The 22 June DC-8 flight sampled over the eastern Pacific (see flight path in Fig. 1c) under these long range transport conditions. Five-day back trajectories using the WRF three dimensional winds were calculated along this day's flight path every $15 \mathrm{~min}$ (Fig. 2b) and show that the sampled air masses travelled in the free troposphere from the western Pacific before arriving at the California coast. Over the southern California near shore portions of the inbound flight path, the flow was at lower altitudes, with air-masses coming from the northern California coast (in purple). 

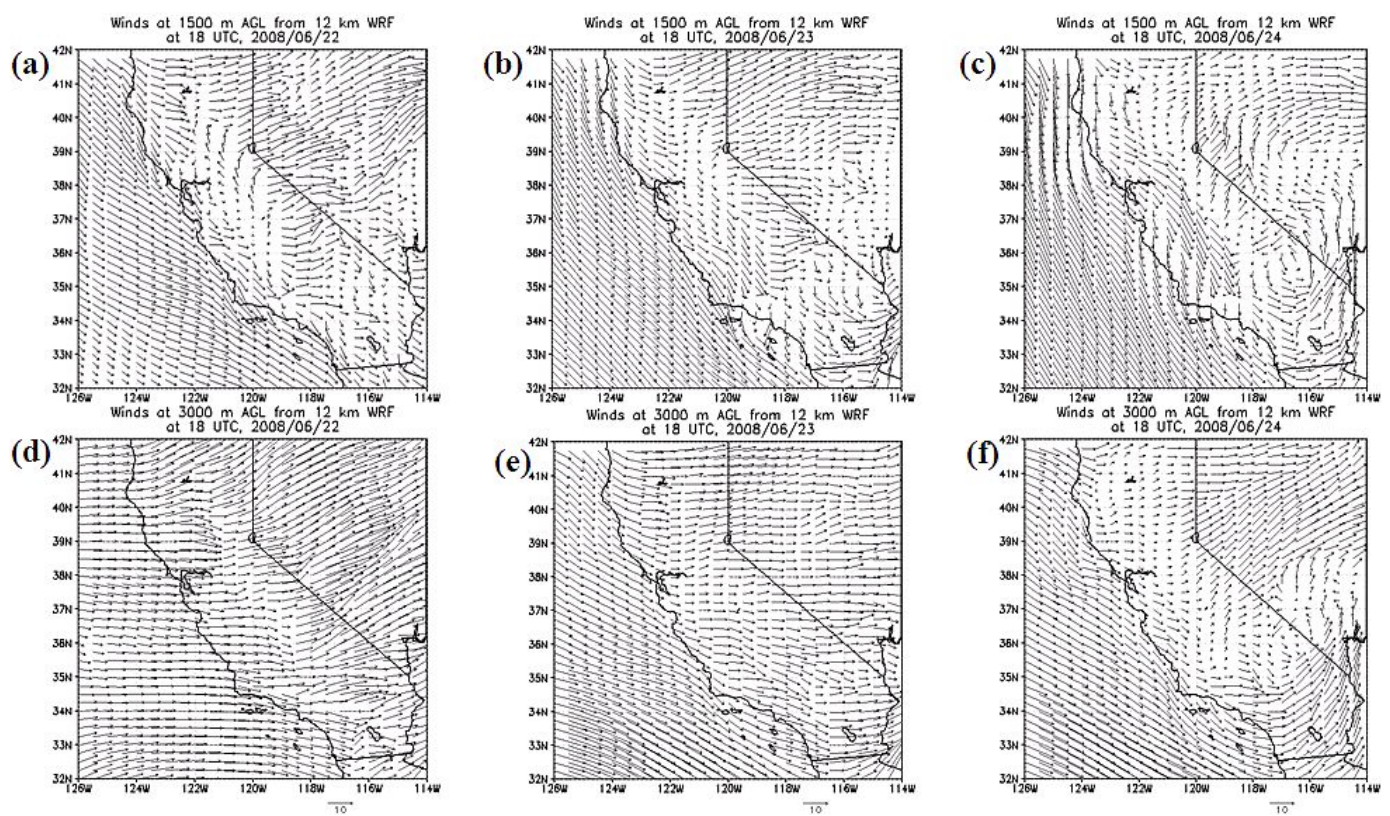

Fig. 3. $12 \mathrm{~km}$ wind fields at roughly $1500 \mathrm{~m} \mathrm{(a-c)} \mathrm{and} 3000 \mathrm{~m}(\mathbf{d}-\mathbf{f})$ above ground level (a.g.l.) over California at 18:00 UTC on 22 June (a; d), 23 (b; e) and 24 (c; f).

The STEM tracer model includes air mass age estimations calculated using chemical clocks (Tang et al., 2004a). The age along the flight paths estimated from a VOC clock as a function of flight altitude and time is shown in Fig. 2a. Along the most of the outer (outbound) flight leg, regardless of altitude, the air was well aged, with high VOC ages $(150-\sim 300 \mathrm{~h})$. Along the inner (inbound) leg the air mass ages were a strong function of altitude, varying from a few hours at low altitude over southern California to 50 to $100 \mathrm{~h}$ at higher altitudes. This reflects the changes in wind direction with altitude as shown in the trajectories. To further identify the regions most heavily influenced by Asia emissions, the $\%$ contributions to anthropogenic primary $\mathrm{CO}$ from China sources for the flight time and region are plotted in Fig. 2c, d. These plots represent the situation when the flight started sampling outbound (18:00 UTC, 22 June) and headed back to Palmdale through inbound (24:00 UTC (00:00 UTC, 23 June)). The $\mathrm{CO}$ contributions from Chinese emissions at the surface were the greatest over northern California and offshore areas of the eastern Pacific, ranging from 20-80\%. Areas south of San Francisco had a much smaller fractional contribution from Asian sources at these times. As shown in Fig. 2d, the on-shore flow persisted and the Asia influence continued to advance to the east.

Further insights into flow conditions during and after this flight period are gained from maps of $12 \mathrm{~km}$ wind vectors at roughly $1500 \mathrm{~m}$ and $3000 \mathrm{~m}$ above ground level (a.g.l.) at 18:00 UTC on 22, 23 and 24 June 2008 (Fig. 3). At 3000 m, onshore westerly winds blew at almost constant speed penetrating inland to California and then extending to Nevada on
22 and 23 June. The wind speed over California decreased on 24 June. The offshore winds at $32-33^{\circ} \mathrm{N}$ were from the southwest on 22 June, and shifted to northwesterly flows when approaching the shore of southern California. These flows continued for the following two days. Coastal winds at $1500 \mathrm{~m}$ were northwesterly, with the Central Valley displaying greater complexity and daily variability due to local orographic features. They became more organized on 23 and 24 June, with northwesterly winds throughout the valley. The southern portions of California were under a low pressure system with southwesterly winds.

Corresponding predicted surface $\mathrm{CO}$ and $\mathrm{O}_{3}$ concentrations from the $12 \mathrm{~km}$ model simulation are shown in Fig. 4. Extensive areas in southern California and the Central Valley were subject to $\mathrm{O}_{3}$ concentrations exceeding $70 \mathrm{ppb}$, especially on 23 and 24 June, as a result of hot and dry weather conditions. On these days air-masses enhanced in $\mathrm{O}_{3}$ and precursors were transported over the ocean and into the northern portion of the valley. They were mixed together with $\mathrm{CO}$ and other precursors emitted during the northern California fire events, and then transported southward where they were mixed with local emissions leading to the high $\mathrm{O}_{3}$ and $\mathrm{CO}$ concentrations.

\subsection{Coastal-inland $\mathrm{O}_{3}$ transport}

As discussed in Sect. 3.1, northern California was impacted by pollution from Asia from 22-24 June. The coastal site at THD is a representative station for characterizing variations in background $\mathrm{O}_{3}$ from the eastern Pacific (Oltmans et al., 
(a) Surtoce co from $12 \mathrm{~km}$ bosec cose
ot 18 UTC $2008 / 06 / 22$

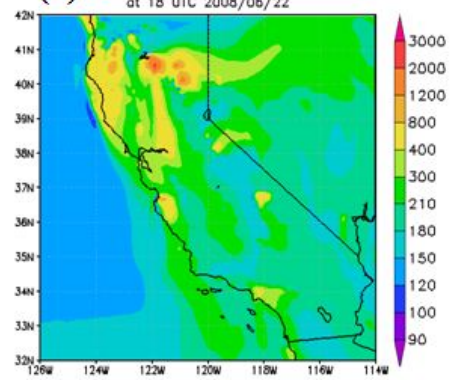

(d) $\begin{gathered}\text { Surfoce } 03 \text { from } 12 k \mathrm{~m} \text { bose cose } \\ \text { ot } 18 \text { ưC } 2008 / 06 / 22\end{gathered}$

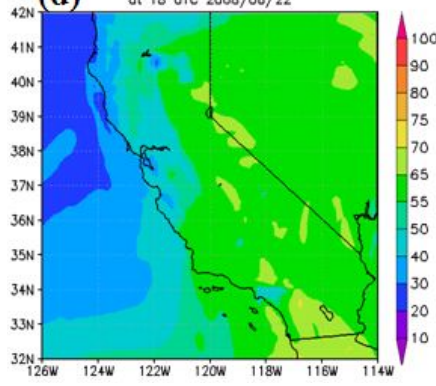

(b) Surfoce co trom $12 \mathrm{~km}$ bose cose
ot 18 Ur $2008 / 06 / 23$

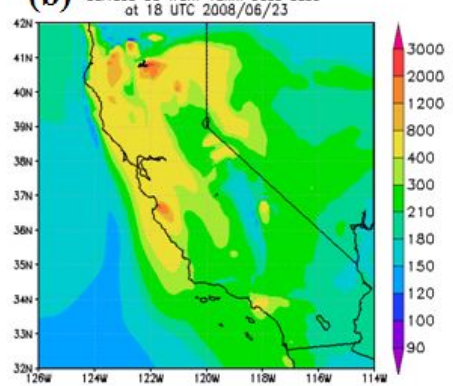

(e) $\begin{gathered}\text { Surfoce } 03 \text { from } 12 \mathrm{~km} \text { bose cose } \\ \text { ot } 18 \text { ưc } 2008 / 06 / 23\end{gathered}$

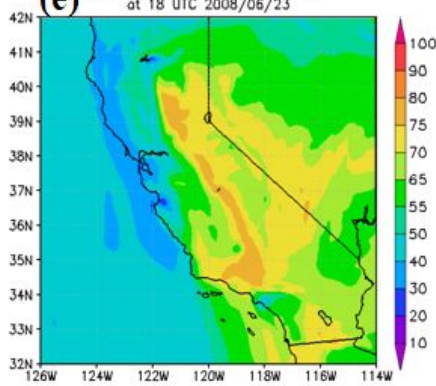

(c) Surfoce co from $12 \mathrm{~km}$ bose cose
ot 18 Ư⿱C $2008 / 06 / 24$

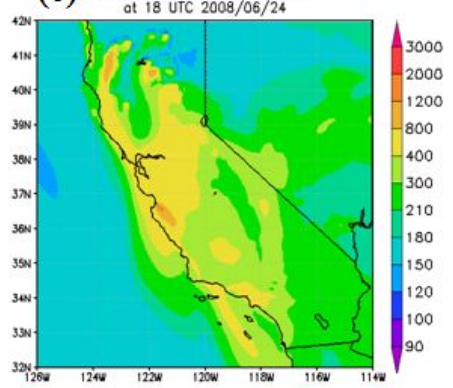

(f) Surfoce 03 from $12 k m$ bose cose
ot 18 UrC $2008 / 06 / 24$

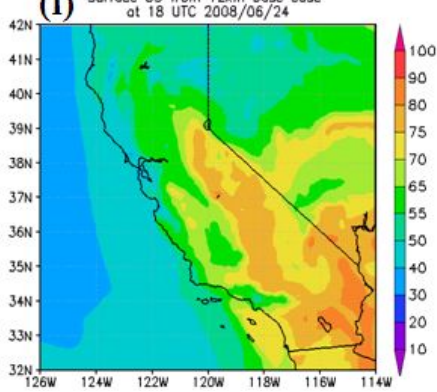

Fig. 4. $12 \mathrm{~km}$ modeled surface $\mathrm{CO}(\mathbf{a}-\mathbf{c})$ and $\mathrm{O}_{3}$ (d-f) over California at 18:00 UTC on 22 June (a; d), 23 (b; e) and 24 (c; f).
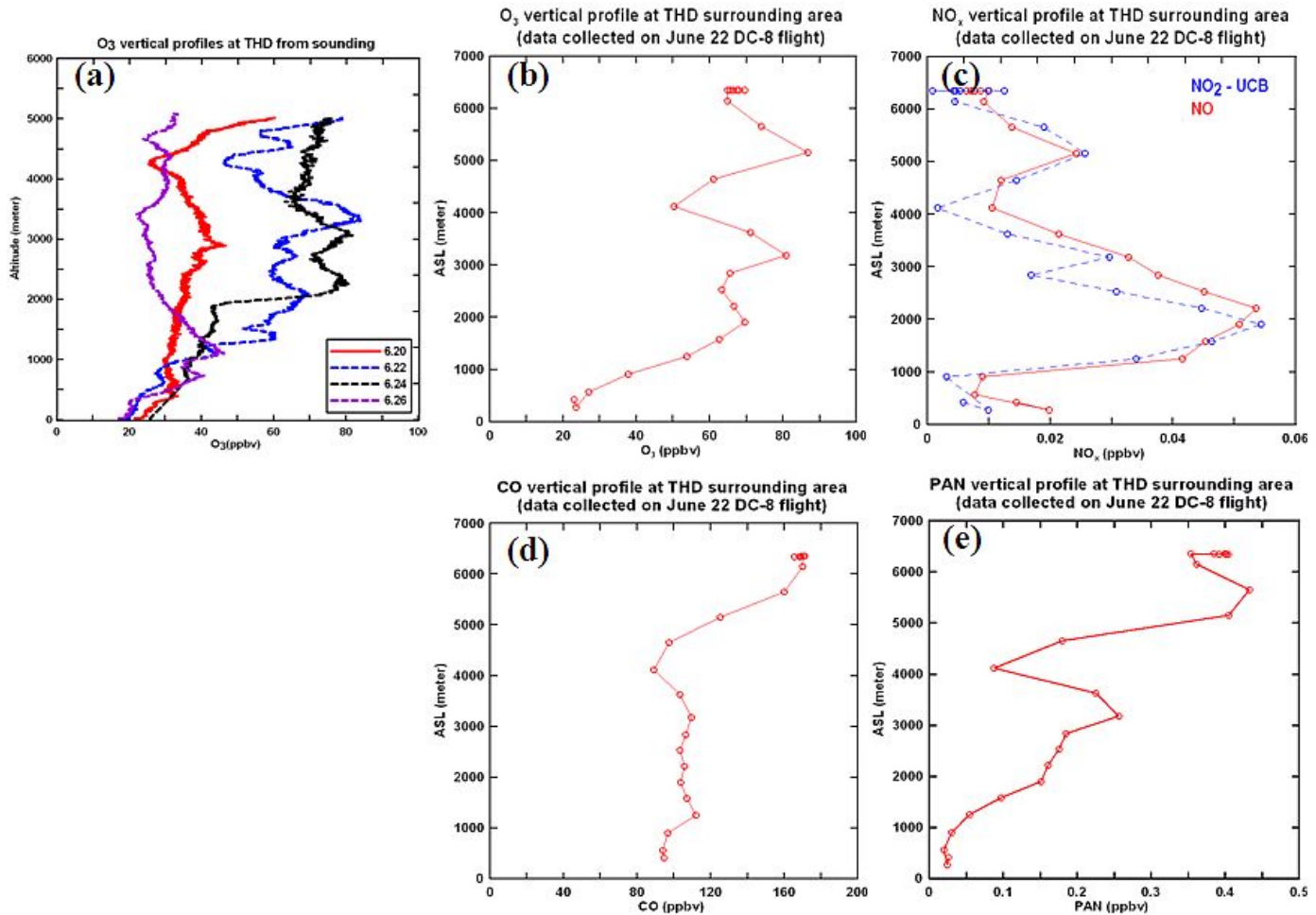

Fig. 5. (a) Observed $\mathrm{O}_{3}$ vertical profiles at THD on four sounding days; (b) $\mathrm{O}_{3}$ (c) $\mathrm{NO}_{\mathrm{x}}$ (d) $\mathrm{CO}$ (e) PAN vertical profiles on 22 June at THD surrounding areas, observed on DC-8.

2008). Observed $\mathrm{O}_{3}$ vertical profiles from sondes launched at THD on four days (with launch times between 18:00 22:00 UTC) are shown in Fig. 5a. Although $\mathrm{O}_{3}$ was consistently between $20-30 \mathrm{ppb}$ near the surface, significantly higher $\mathrm{O}_{3}$ (with values ranging from $60-80 \mathrm{ppb}$ ) was ob- served on 22 and 24 June, at altitudes between $1500 \mathrm{~m}$ and $3500 \mathrm{~m}$. In contrast, on the relatively cleaner days of 20 and 26 June, $\mathrm{O}_{3}$ concentrations stayed below $50 \mathrm{ppb}$ at altitudes below $5000 \mathrm{~m}$. These results illustrate the large $\mathrm{O}_{3}$ variability in the air masses transported into California during 

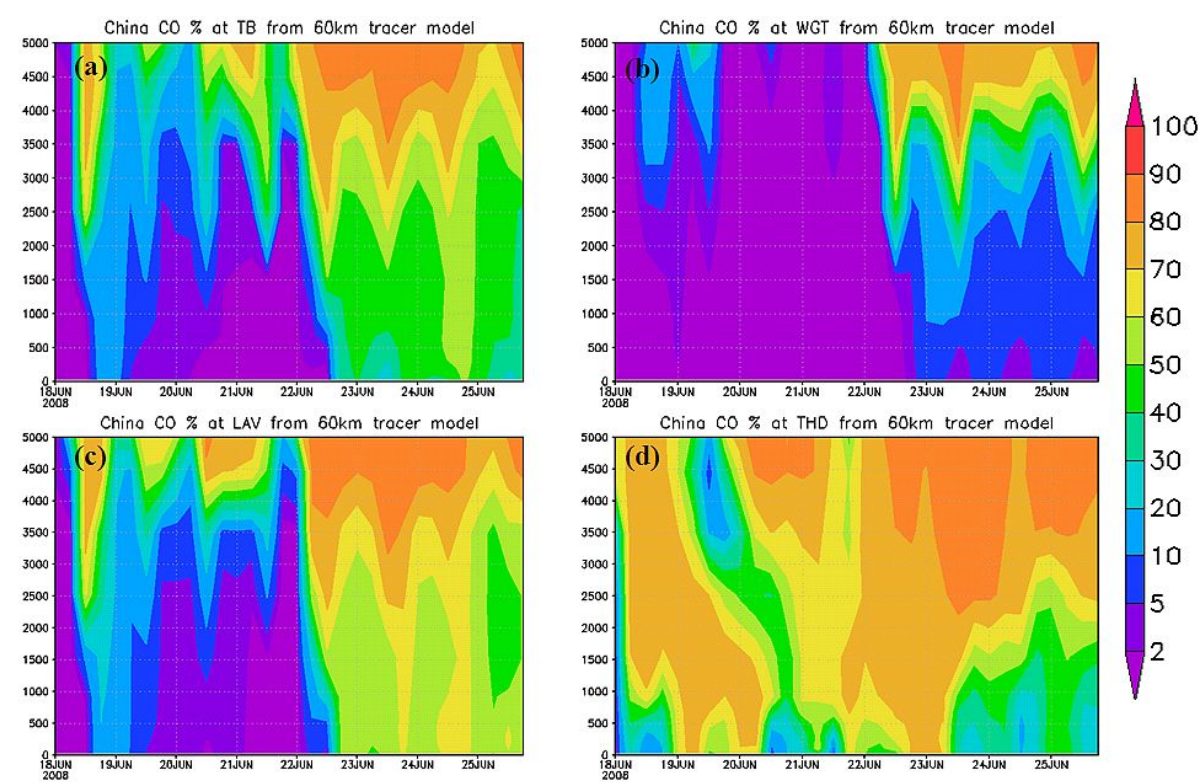

Fig. 6. Time-height (a.g.l., m) curtain plots of anthropogenic China CO contributions as \% across sites at (a) TB (b) WGT (c) LAV and (d) THD. Their elevations are $572 \mathrm{~m}, 0 \mathrm{~m}, 1756 \mathrm{~m}$ and $20 \mathrm{~m}$, respectively.

summertime. Figure 5b-e show the vertical profiles of several chemicals sampled by DC- 8 near the THD site at approximately the same time as the $\mathrm{O}_{3}$ sounding was launched on 22 June. $\mathrm{O}_{3}$ concentrations show similar vertical structure as the THD $\mathrm{O}_{3}$ sonde results. The PAN and $\mathrm{NO}_{2}$ profiles are highly correlated with the $\mathrm{O}_{3}$ profiles. The $\mathrm{CO}$ profile shows three general segments as identified from the tagged tracer CO results (not shown): marine air below $\sim 1 \mathrm{~km}$; a mid region from 1 to $5 \mathrm{~km}$, where CO structure is the result of a mixture of Asian anthropogenic sources and biomass burning from North America (below $\sim 2 \mathrm{~km}$ ); and an upper segment (above $5 \mathrm{~km}$ ), which is a mixture of anthropogenic and biomass burning from Asia.

Further insights into the Asia influence at THD and at inland sites is shown in the time-height curtain plots of China CO contributions (Fig. 6). The THD site was heavily influenced by Asian emissions throughout this period, with persistent Asia influence above $\sim 2 \mathrm{~km}$, and several episodes with the significant influence reaching the surface. The situation on 22 June shows a strong ( $>60 \%)$ influence from Asia above $1 \mathrm{~km}$. This transport event strongly impacted inland regions of northern California. The China CO contributions jumped from below $2 \%$ to above $40 \%$ by the end of 22 June at the TB and LAV sites (see Fig. 1c for site locations). China inflows also affected the WGT site, but accounted for less than $10 \%$ at the surface. At this site the strong Asia influence was at higher altitudes (above $\sim 3 \mathrm{~km}$ ). In contrast, the impacts of Chinese sources were very small at the southern California JOT site (not shown). The influences of transported background $\mathrm{O}_{3}$ during these Asian inflows periods at four inland surface sites were also analyzed. The time-height
$\mathrm{O}_{3}$ distributions from the $12 \mathrm{~km}$ simulation (Fig. 7) clearly show that $\mathrm{O}_{3}$ transported above the boundary layer can impact the surface as air-masses descend and entrain into the boundary layer. The $\mathrm{O}_{3}$ vertical structure shows the combined impacts of local production in the boundary layer, as well as long-range transport at higher altitudes.

To further understand the flow characteristics associated with periods of observed high $\mathrm{O}_{3}$ values, we estimated $\mathrm{O}_{3}$ distributions backward in time by combining the corresponding observed values with air-mass back trajectories. In this methodology, we take the observed concentration and propagate its value backwards in time along a wind trajectory. By running multiple trajectories, and assuming that the value does not change along that trajectory we can identify the general flow conditions and upwind regions associate with high $\mathrm{O}_{3}$ values. In this method the geographic region covered by the trajectories was divided into an array of $1^{\circ} \times 1^{\circ}$ grid cells, and the location of an air parcel at a particular time was represented by the trajectory segment latitude and longitude endpoints. The average concentration colored on each grid cell was calculated by the mean observed $\mathrm{O}_{3}$ concentrations associated with each trajectory endpoint that landed in the surface grid at the discrete time intervals (Kurata et al., 2004). In this way, we colored three-day back trajectories originating from four surface sites on 23 June, based on the $12 \mathrm{~km}$ WRF meteorology fields (Fig. 8). The starting times used were from 00:00 UTC to 23:00 UTC with one-hour interval. Results at LAV and TB sites show that the high observed surface $\mathrm{O}_{3}$ levels periods were associated with inflows from the eastern Pacific and the coastal area. In contrast, high $\mathrm{O}_{3}$ periods at the WGT site were associated with flows passing over 

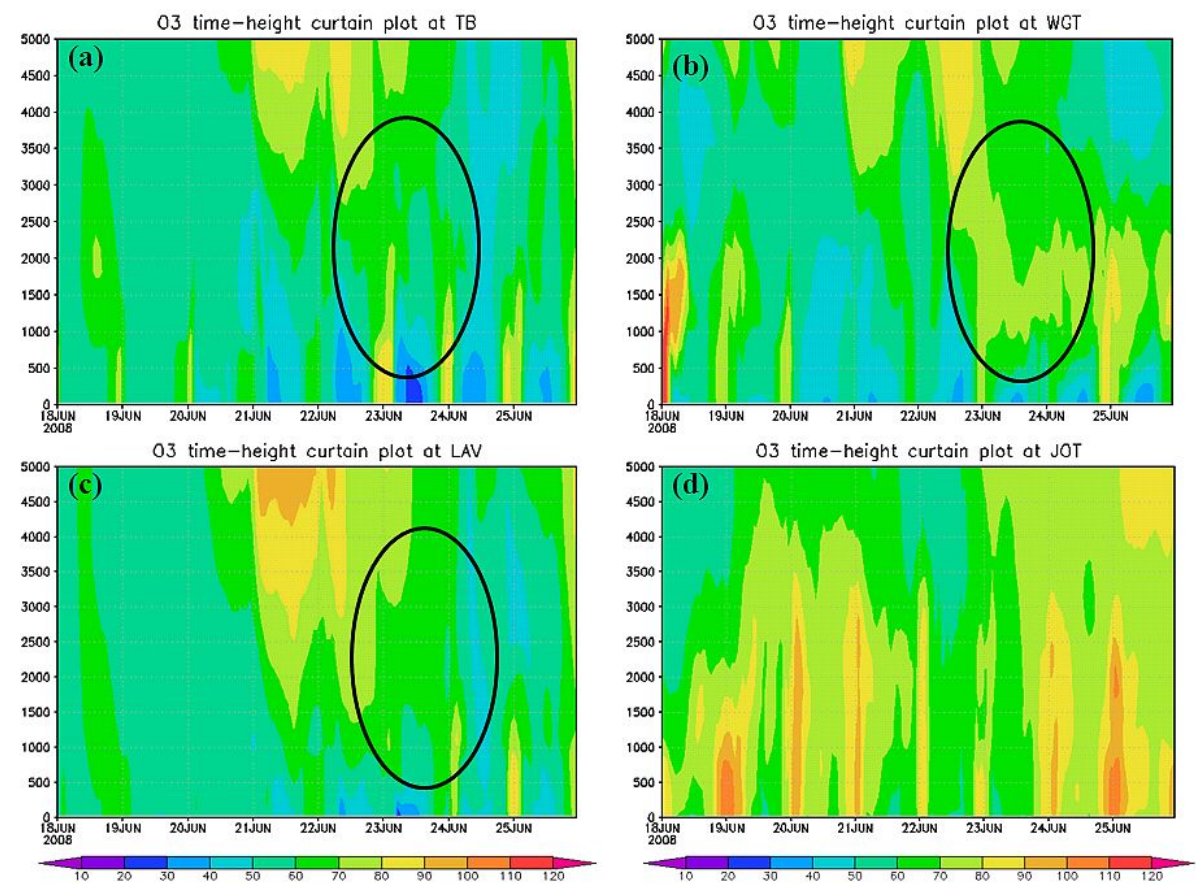

Fig. 7. $\mathrm{O}_{3}$ time-height (a.g.l., $\mathrm{m}$ ) curtain plots from the $12 \mathrm{~km}$ base case across sites at (a) TB (b) WGT (c) LAV and (d) JOT. Their elevations are $572 \mathrm{~m}, 0 \mathrm{~m}, 1756 \mathrm{~m}$ and $20 \mathrm{~m}$, respectively.
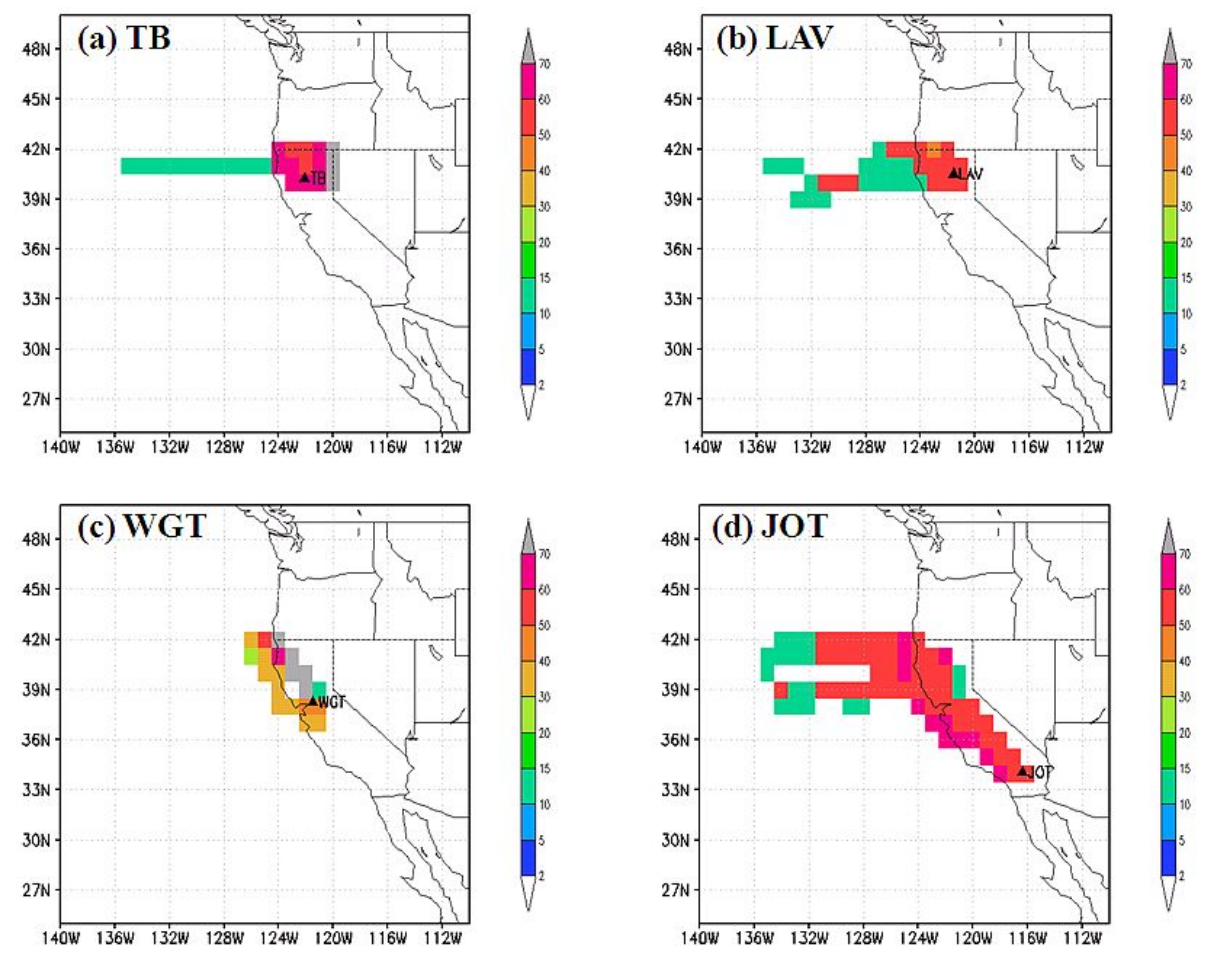

Fig. 8. Reconstructed $\mathrm{O}_{3}$ concentrations along three-day back trajectories from $12 \mathrm{~km}$ meteorological fields originating at (a) TB (b) LAV (c) WGT and (d) JOT on 23 June. 
near-coastal areas of northern California as well as flows directly from the San Francisco Bay area. The high $\mathrm{O}_{3}$ levels at JOT were associated with flows through the Central Valley, with some flows extending out into the eastern Pacific.

To further characterize the influence of $\mathrm{O}_{3}$ over the eastern Pacific on surface $\mathrm{O}_{3}$ over California we examined spacetime correlations. Specifically, we calculated correlations between THD $\mathrm{O}_{3}$ at multiple elevations and surface $\mathrm{O}_{3}$ at inland sites for different hourly time offsets. We calculated $\mathrm{R}$-square values using both observational and modeled data and the results for the TB site are shown in Fig. 9. Observed $\mathrm{O}_{3}$ time series at THD were constructed using $\mathrm{O}_{3}$ sonde data at THD on 20, 22, 24 and 26 June. Soundings for each day were averaged every $500 \mathrm{~m}$ up to $5000 \mathrm{~m}$ a.g.l. Averages for each altitude bin were interpolated to hourly values using a univariate interpolation approach (Akima, 1970), and the resulting altitude-specific time series were then correlated with the time series built from hourly surface $\mathrm{O}_{3}$ observations at the TB site. Resultant correlations between $\mathrm{O}_{3}$ at three altitude bins (1000-1500 m, 2500-3000 m, and 3500-4000 m) above THD and surface $\mathrm{O}_{3}$ at TB are shown in Fig. 9c. High $\mathrm{R}$-square values ranged from 0.67 to 0.75 at these altitudes, indicating strong correlations between surface $\mathrm{O}_{3}$ at the TB site and $\mathrm{O}_{3}$ at all three altitudes above THD during 21 June24 June. Surface $\mathrm{O}_{3}$ at the TB site was most highly correlated with $\mathrm{O}_{3}$ at 2500-3000 $\mathrm{m}$ above THD with a time lag of around $30 \mathrm{~h}$.

This analysis was repeated using $12 \mathrm{~km}$ modeled data, correlating hourly concentrations at THD at the same altitudes with predicted hourly surface $\mathrm{O}_{3}$ at TB. Predicted $\mathrm{O}_{3}$ vertical structures on 22 June at THD and the time series at TB are compared with observations in Fig. 9a and b. The predicted values captured the ozone enhancement between $\sim 1.5$ to $4 \mathrm{~km}$ as observed at THD, and many of the important features in the time series of ozone at TB. Model-based correlations in Fig. 9d and e show correlations across several time offsets, due to the higher fidelity of the time series used in analysis. The highest R-square value was 0.68 , found at $2500 \mathrm{~m}$ with a time offset of $22 \mathrm{~h}$, shorter than the $30 \mathrm{~h}$ offset found in the observational data.

To better understand the causes of these $\mathrm{O}_{3}$ transport correlation relationships, we plot the forward trajectories in Fig. 10a, b from the $12 \mathrm{~km}$ meteorology fields originating on 22 June, from $1500 \mathrm{~m}$ and $2500 \mathrm{~m}$ above THD, respectively. The starting times were from 00:00 UTC to 23:00 UTC with a one-hour interval. On this day, the winds blew from $\sim 2500 \mathrm{~m}$ above THD directly to northern California (Fig. 10b). The forward trajectory starting at $2500 \mathrm{~m}$ above THD at 01:00 UTC on 22 June (06:00 p.m. LT, 21 June) is shown in Fig. 10d. The air-mass descended as it traveled inland into the valley, reaching the east side of the valley after about $17-18 \mathrm{~h}$, where it affected the TB surface concentrations at the end of 22 June. Upslope mountain-valley flows in the afternoon lifted the air-masses, and they continued moving east. At $1500 \mathrm{~m}$, the wind directions were more varied leading to the impact being more dispersed, affecting TB, Nevada as well as large areas south of THD. This analysis shows clearly the inland transport and entrainment of the eastern Pacific $\mathrm{O}_{3}$ into the boundary layer.

The origin of the air masses reaching $\mathrm{TB}$ are shown to be a mixture of air from Oregon transported at low altitudes $(<\sim 1500 \mathrm{~m})$, as well as air transported from the eastern Pacific at attitudes between 1.5 to $3 \mathrm{~km}$ as shown in Fig. 10c. These back-trajectories of air masses at about 400$500 \mathrm{~m}$ above TB area were calculated from 00:00 UTC to 23:00 UTC with one-hour intervals on 22 and 23 June. We plot the back trajectory of an air mass at about 400-500 m above TB area at 00:00 UTC on 23 June (05:00 p.m. LT, 22 June) in Fig. 10e. This air-mass was at $3500-4000 \mathrm{~m}$ above the eastern Pacific $40 \mathrm{~h}$ earlier. It then passed THD at $\sim 3000 \mathrm{~m}$ above sea level (a.s.l.) and descended east into the valley, taking $\sim 22 \mathrm{~h}$ to travel from the coast to the valley, where the pollutants were finally mixed down to the surface.

The correlation between THD $\mathrm{O}_{3}$ at multiple elevations and surface $\mathrm{O}_{3}$ at inland sites varied throughout the ARCTAS-CARB period. Figure 9d and e show the model correlations between THD at $1500 \mathrm{~m}$ and $2500 \mathrm{~m}$ and the TB site at different time offsets for the 18-28 June period. Over this longer analysis time period, no significant correlations were observed at $2500 \mathrm{~m}$. But at $1500 \mathrm{~m}$, a lower maximum $\mathrm{R}$-square of 0.3 was obtained for a 30 -h transport time. These results are similar to those from the correlation study using 8-h average $\mathrm{O}_{3}$ based on multi-year observations (Parrish et al., 2010), and can be further explained with air-mass trajectories (Fig. 11).

Similar as Fig. 10a-c, Fig. 11 shows the forward trajectories from the $12 \mathrm{~km}$ meteorology fields originating from $1500 \mathrm{~m}$ and $2500 \mathrm{~m}$ above THD, together with the backtrajectories of air masses at about $400-500 \mathrm{~m}$ above TB area, for every hour on 20 June (before the long-range transport event). The air-masses on this day at $2500 \mathrm{~m}$ above THD blew directly to Oregon and had no direct impact over the TB area. The air-masses at $1500 \mathrm{~m}$ above THD blew directly to the northern California including the TB area, but stayed at $\sim 1200-1500 \mathrm{~m}$ above the valley surface. The pollutants they carried were mixed down to the surface during day time as the boundary layer grew. The back-trajectories in Fig. 11c also indicate that the air-masses over the TB area were mainly from below $1500 \mathrm{~m}$ above the Eastern Pacific on this day.

These results show that surface $\mathrm{O}_{3}$ in northern California can be directly influenced by $\mathrm{O}_{3}$ transported over the eastern Pacific in summer. Near the coast the influence is limited as the $\mathrm{MBL} \mathrm{O}_{3}$ concentrations are typically below $40 \mathrm{ppb}$. However, inland, the influence of $\mathrm{O}_{3}$, transported at higher altitudes is strengthened; there coastal $\mathrm{O}_{3}$ levels can reach 60-80 ppb. The enhancement of $\mathrm{O}_{3}$ over the ocean at higher altitudes significantly affects downwind surface $\mathrm{O}_{3}$ concentrations. 

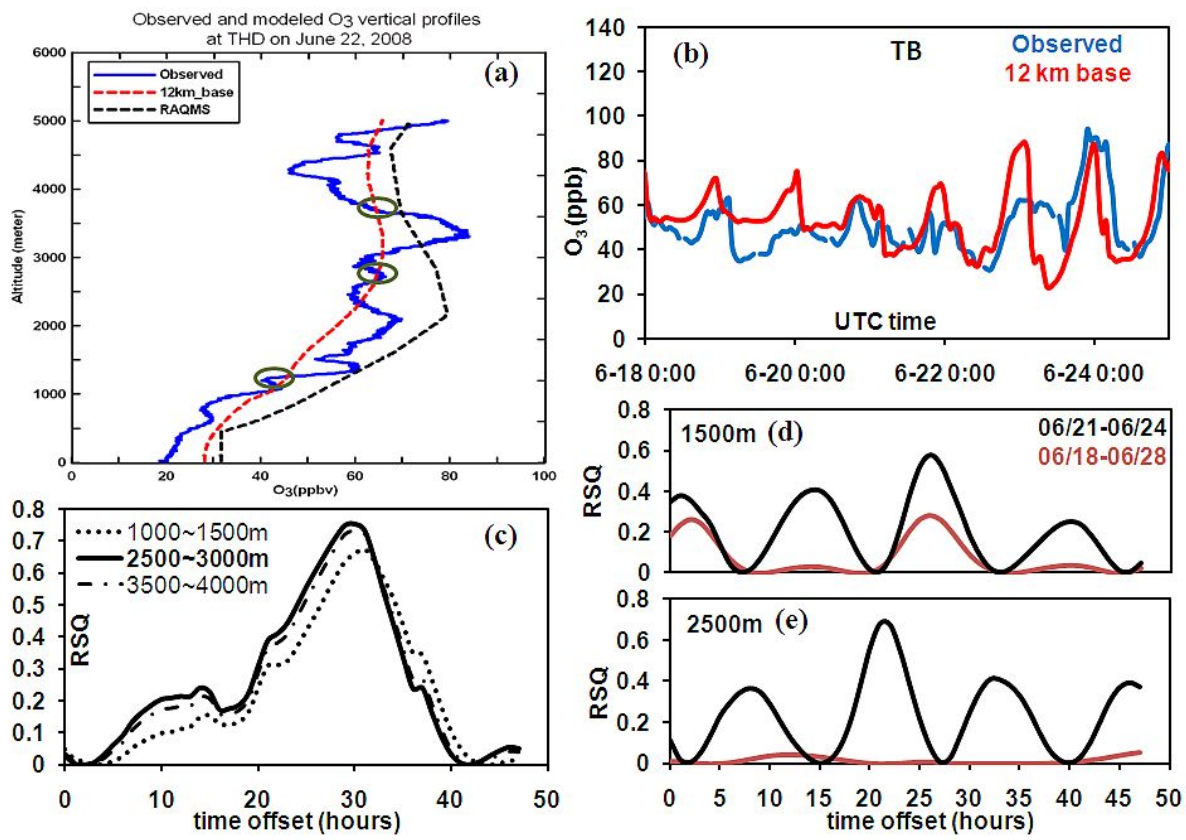

Fig. 9. Observed and $12 \mathrm{~km}$-modeled $\mathrm{O}_{3}$ profiles at (a) THD and (b) TB; the correlation analysis based on (c) observations and (d-e) $12 \mathrm{~km}$ model results.

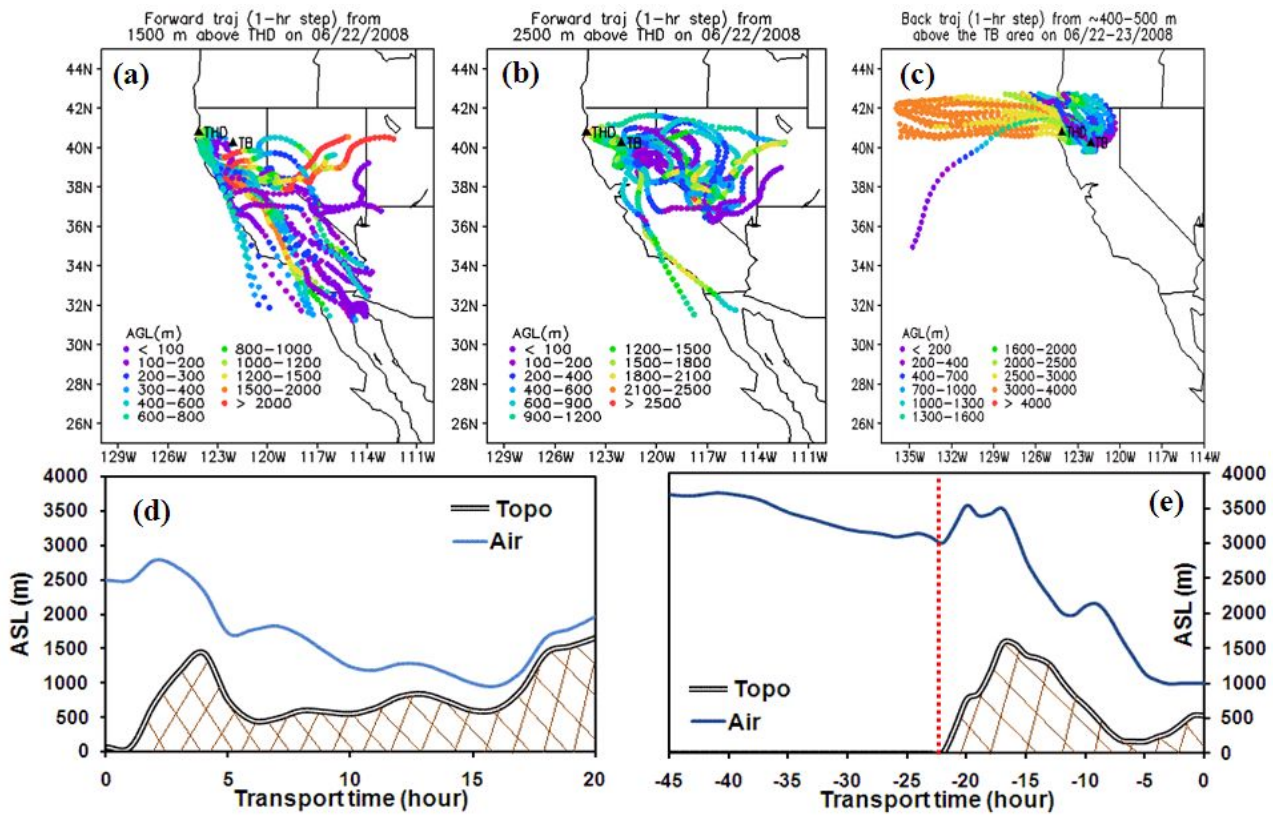

Fig. 10. Forward trajectories originating on 22 June from (a) $1500 \mathrm{~m}$ (b) $2500 \mathrm{~m}$ above THD; (c) back trajectories originating from $400-$ $500 \mathrm{~m}$ above TB area; transport height as a function of time along with topography along the (d) forward trajectory originating from $2500 \mathrm{~m}$ above THD, 22 June 01:00 UTC (e) back trajectory originating at 400-500 m above TB area, 23 June 00:00 UTC Fig. 11. Forward trajectories originating on 20 June from (a) $1500 \mathrm{~m}$ (b) $2500 \mathrm{~m}$ above THD; (c) Back trajectories originating from 400-500 $\mathrm{m}$ above TB area.

The situation in southern California is different. As discussed in the introduction, the $\mathrm{O}_{3}$ entering southern California directly from the eastern Pacific in the summer is very similar in magnitude and vertical structure to that measured at THD. However, the southern California coastal ranges are not as high and continuous as in northern California. Thus southern California is often under the influence of on-shore marine boundary layer flows, which bring lower levels of background $\mathrm{O}_{3}$ that then mix with the high emission regions. Therefore, it is more difficult to detect the influence of this 

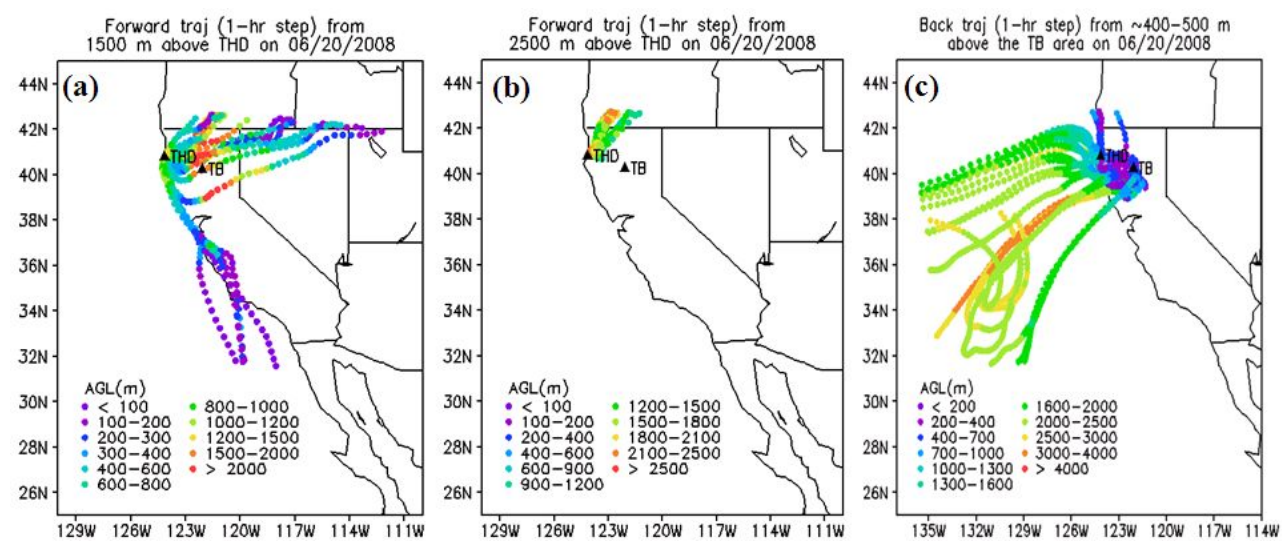

Fig. 11. Forward trajectories originating on 20 June from (a) $1500 \mathrm{~m}$ (b) $2500 \mathrm{~m}$ above THD; (c) back trajectories originating from $400-$ $500 \mathrm{~m}$ above TB area.

eastern Pacific $\mathrm{O}_{3}$ on inland surface observations in southern California. During this analysis period, we did not have a situation where air over the southern portion of the eastern Pacific at altitudes from 1.5 to $4 \mathrm{~km}$ had a significant direct impact on $\mathrm{O}_{3}$ at the JOT site in southern California.

\subsection{Model LBC sensitivity studies}

Considering the significance of $\mathrm{O}_{3}$ transported from the eastern Pacific on California surface $\mathrm{O}_{3}$, the uncertainties in the model western LBC along with the meteorological conditions can represent a significant source of error in the prediction of surface $\mathrm{O}_{3}$ over California. To evaluate the impact of the western LBC on surface $\mathrm{O}_{3}$ predictions over California, a series of LBC sensitivity simulations were performed in the $60 \mathrm{~km}$ model grid. These tests were done using the $60 \mathrm{~km}$ grid as this resolution is representative of that used in higher resolution global chemical transport models (CTMs) and that used in the outer grid in nested air quality models.

There are several methods to create LBCs including using constant values, default profile gradients, and real-time profiles downscaled from global model results. Here we show results for simulations using the various approaches summarized in Table 2. The Clean WBC case resulted in a decrease relative to the base case in California surface $\mathrm{O}_{3}$, with large changes (exceeding $5 \mathrm{ppb}$ ) extending over two thirds of the study domain, and the decrease over northern California was generally higher than $12 \mathrm{ppb}$. The time series of surface $\mathrm{O}_{3}$ values and their change due to the use of the Clean WBC at $\mathrm{TB}$ are shown in Fig. 12b and $\mathrm{f}$. The largest changes in $\mathrm{O}_{3}$ (>20 ppb) occurred after 22 June, and correspond to the arrival time of Asia-influenced air as discussed earlier (Fig. 6). The Clean WBC case represents a typical default value often used in air quality studies. These results demonstrate the importance of a better representation of the western LBC in order to improve model predictions.
A better representation of the LBC can be obtained by downscaling results from global chemical transport models. Tang et al. (2007) demonstrated that LBCs derived from global models can capture much of the temporal and spatial variability along the boundary and can enhance air quality predictions. Recall that for the base simulation we took this approach and used results from the RAQMS global model as the LBC in our $60 \mathrm{~km}$ base simulations. The RAQMSpredicted $\mathrm{O}_{3}$ values were directly compared with the $\mathrm{O}_{3}$ sondes at THD on 22 June (Fig. 9a) and the observations for the 22 June DC-8 flight are shown in Fig. 13. RAQMS predictions captured the vertical gradients but generally over predicted $\mathrm{O}_{3}$ by $10-20 \mathrm{ppb}$ from surface to $5000 \mathrm{~m}$. $\mathrm{O}_{3}$ values along the flight path are shown in terms of a vertical distribution and as a function of flight altitude and time (Fig. 13a, b). For this flight the RAQMS model over-predicted $\mathrm{O}_{3}$ between $1.5-4 \mathrm{~km}$, and showed less variability than the observations above $1 \mathrm{~km}$. The $60 \mathrm{~km}$ base case simulation is also presented in Fig. 13. The $60 \mathrm{~km} \mathrm{O}_{3}$ values are slightly higher than RAQMS and the observations below $1 \mathrm{~km}$, lower between $1.5-4 \mathrm{~km}$ (and closer to observations), closer to the RAQM results at $5-8 \mathrm{~km}$, and higher than the observations above $8 \mathrm{~km}$. These results show that while the use of global model LBCs can improve model performance, biases can be introduced. In this case the high bias in the RAQMS LBC at THD and along the 22 June flight path at $1.5-4 \mathrm{~km}$ contributed to the over prediction of $\mathrm{O}_{3}$ at the TB site that is shown in Fig. 12a-c.

Additional simulations were performed to further explore the sensitivity of the predictions to the LBC. To explore the importance of temporal variability we used 20-day temporal averaged RAQMS boundary conditions in the Fixed BC case. For this case the predicted surface $\mathrm{O}_{3}$ during 21-24 June dropped 3-7 ppb over more than two-thirds of California. As shown in Fig. 12e, the use of temporally averaged boundary conditions resulted in a decrease in predicted $\mathrm{O}_{3}$ relative to the base case by $\sim 10 \mathrm{ppb}$, during the periods with large Asia 

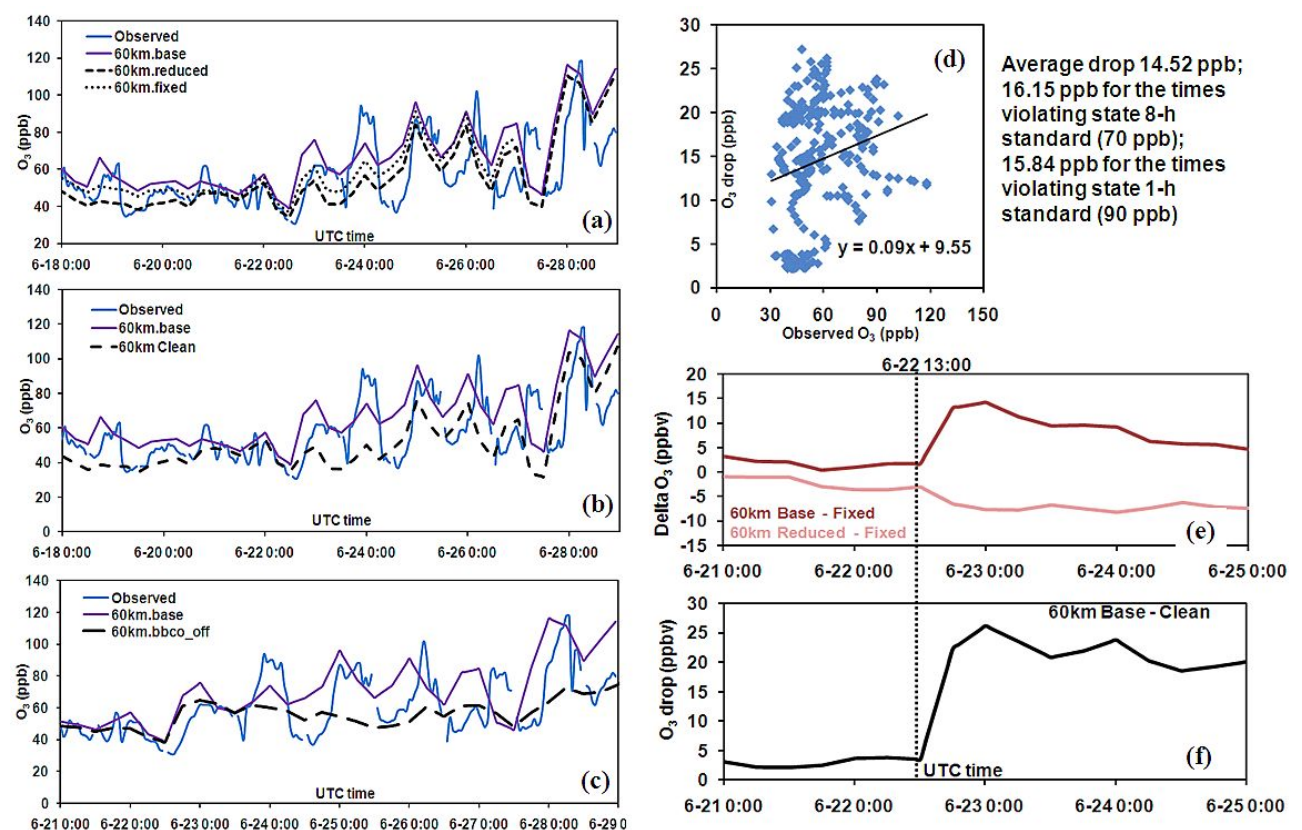

Fig. 12. Time series plots of observed and $60 \mathrm{~km}$ modeled ((a) base case, reduced and fixed sensitivity cases during 18-28 June (b) base case and clean WBC case during 18-28 June (c) base case and sensitivity case without fire emissions during 21-24 June) $\mathrm{O}_{3}$ at TB; (d) scatter plot of delta $\mathrm{O}_{3}$ (between base case and clean WBC case) and observed $\mathrm{O}_{3}$ at TB; time series plots of the delta $\mathrm{O}_{3}((\mathbf{e})$ between base case and Fixed BC case, Reduced WBC case and Fixed BC case (f) between base case and clean WBC case at TB) from $60 \mathrm{~km}$ simulations at TB during 21-24 June.
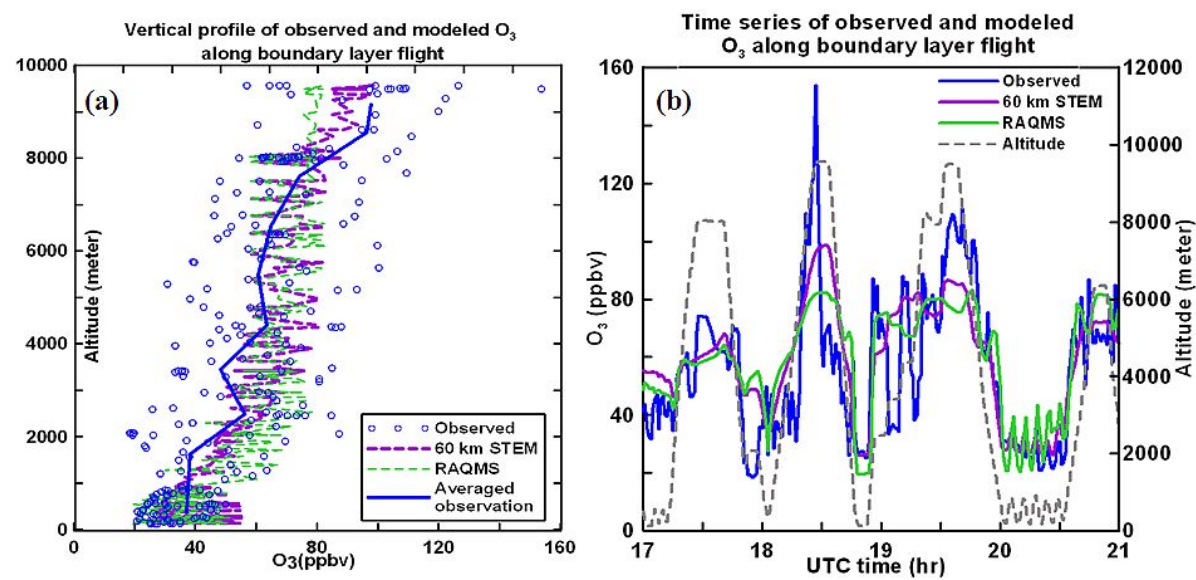

Fig. 13. Observed and modeled (60 km STEM and RAQMS) $\mathrm{O}_{3}$ (a) vertical profiles and (b) time series plots along oceanic flight path. RAQMS and $60 \mathrm{~km}$ STEM base results were used as the boundary conditions for $60 \mathrm{~km}$ and $12 \mathrm{~km}$ STEM base cases respectively.

influence. This is due to the fact that the episodic Asian enhancements were largely removed by the time-averaging of the LBC. The results for the sensitivity simulations where a bias in the western $\mathrm{LBC}$ of $-10 \mathrm{ppb}$ of $\mathrm{O}_{3}$ was added to the Fixed BC case are also shown in Fig. 12a and e. Results from this constant perturbation case helps illustrate how the boundary values are modified within the STEM model. Average changes of surface $\mathrm{O}_{3}$ over California during 1-24 June vary from $1-6 \mathrm{ppb}$, relative to the fixed $\mathrm{BC}$ case. Time vari- ations of changes in $\mathrm{O}_{3}$ at the TB site are shown in Fig. 12e, and 1-8 ppb of $\mathrm{O}_{3}$ decreases can be seen. The extent to which the $\mathrm{O}_{3}$ signal was damped (i.e., lower than the $10 \mathrm{ppb}$ perturbation) reflects the degree to which $\mathrm{O}_{3}$ levels were influenced by local meteorological and chemical processes. The smaller the change is, the larger the influence of the local contributions. 

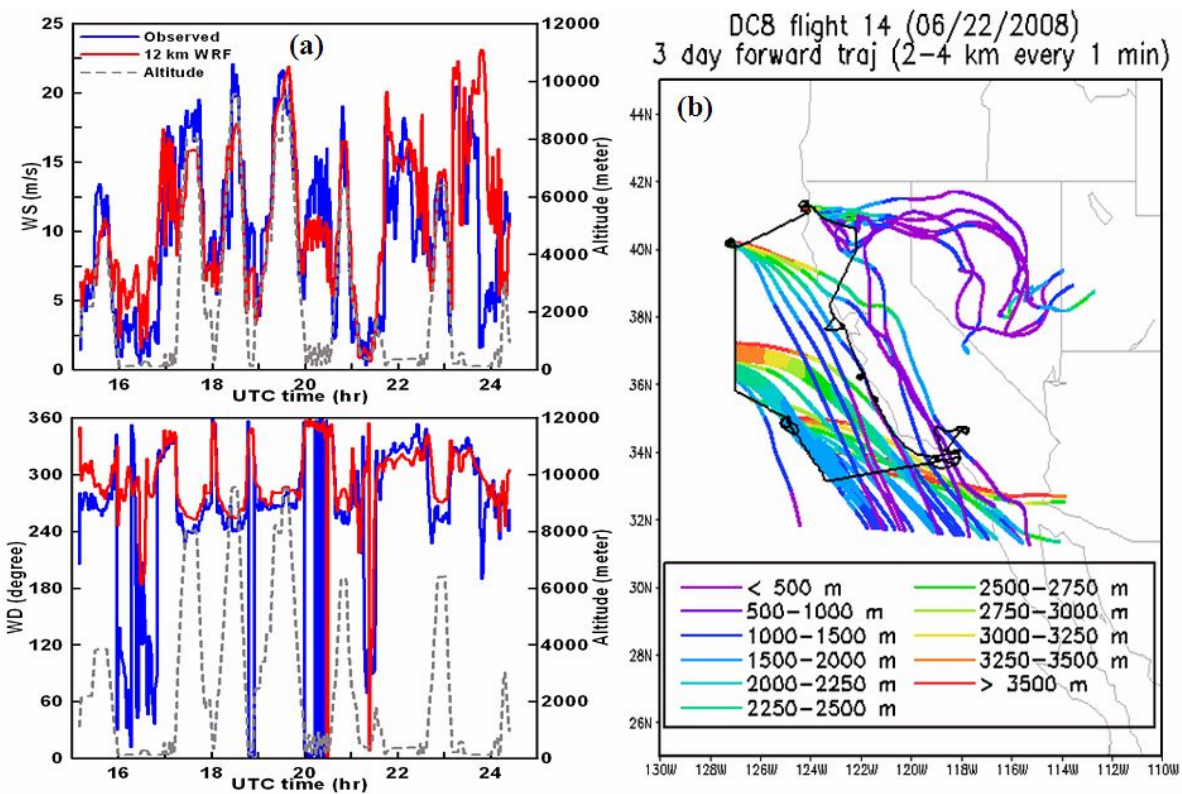

Fig. 14. (a) Observed and $12 \mathrm{~km}$ WRF-modeled wind fields along the 22 June DC-8 flight path; (b) forward trajectories originating at $2-4 \mathrm{~km}$ of the oceanic part of the same flight.

Figure 12a-d illustrate the model sensitivity to western LBC over a longer period of time (18-28 June). By using the clean western $\mathrm{LBC}$, the predicted $\mathrm{O}_{3}$ at the TB site was $14.5 \mathrm{ppb}$ lower than the base case on average. At the times that 8-hr $\mathrm{O}_{3}>70 \mathrm{ppb}$ (CA state standard), the difference was $\sim 16.2 \mathrm{ppb}$ on average. The largest decreases occurred during 18-19 June and 23-24 June, and the smallest $\mathrm{O}_{3}$ were on 21 June and early 22 June. During these two periods larger differences are shown in Fig. 12a between the base and fixed LBC cases, as well as between the Fixed LBC and reduced LBC cases. As stated earlier during the study period there were active biomass-burning fires. Figure 12c compares the time series of observed and predicted $\mathrm{O}_{3}$ with and without biomass burning emissions. The biomass burning emissions had a larger impact on predicted $\mathrm{O}_{3}$ after 25 June, and caused the modeled $\mathrm{O}_{3}$ to be less sensitive to the $\mathrm{LBC}$.

Figure $12 \mathrm{~d}$ shows that the $1-\mathrm{h} \mathrm{O}_{3}$ differences between base and the Clean WBC cases generally increase as the observed $\mathrm{O}_{3}$ increases, with a mixture of slopes. The range in slopes indicates varied enhancements of $\mathrm{O}_{3}$ in the western $\mathrm{LBC}$, as well as the different model sensitivity to LBC under Asian events and fire events.

\subsection{Model performance improvements}

\subsubsection{Methodology}

Further improvements in model prediction will require reducing the uncertainties in the LBCs. The 22 June ARCTASCARB flight devoted to characterizing the LBC under Asian inflow conditions provided data to test how additional obser- vations can help to improve the LBC. We performed an additional simulation where we used the observations over the eastern Pacific as the western LBC in the $60 \mathrm{~km}$ model domain. Sampled concentrations for eight gaseous pollutants $\left(\mathrm{NO}, \mathrm{NO}_{2}, \mathrm{CO}, \mathrm{O}_{3}, \mathrm{H}_{2} \mathrm{O}_{2}, \mathrm{PAN}, \mathrm{HNO}_{3}\right.$ and $\mathrm{SO}_{2}$ ) were averaged every $1000 \mathrm{~m}$. The mean $\mathrm{O}_{3}$ profile used for this case is also shown in blue in Fig. 13a. We vertically interpolated these values to STEM grids, and replaced the RAQMS western LBC with these observation-based vertical gradients, in both $60 \mathrm{~km}$ and $12 \mathrm{~km}$ grids for the flight week. To identify the regions where we would expected to see the biggest changes in model predictions using the observational-based (Obs case) western LBC, we calculated forward trajectories along the flight path using the $12 \mathrm{~km}$ WRF meteorology fields. The $12 \mathrm{~km}$ WRF meteorology is compared with the aircraft observations along the flight path in Fig. 14a. In general the $12 \mathrm{~km}$ simulation is able to capture the main features of the flow fields. The trajectories (every one minute) for flight altitudes at $2-4 \mathrm{~km}$ above the eastern Pacific are shown in Fig. 14b. Air-masses sampled by the aircraft are shown to travel forward in time at multiple vertical layers and then descend into the Sacramento Valley, the west ridge of the Central Valley, and along coastal southern California.

\subsubsection{Model performance improvement at the surface}

The impact of the observational-based LBC on the $60 \mathrm{~km}$ predictions is shown in Fig. 15, where the surface $\mathrm{O}_{3}$ difference (Base case - Obs case) over California at 18:00 UTC (11:00 a.m. local time) on 22, 23 and 24 June is plotted. At 18:00 UTC on 22 June, $\mathrm{O}_{3}$ dropped 8-12 ppb over northern 

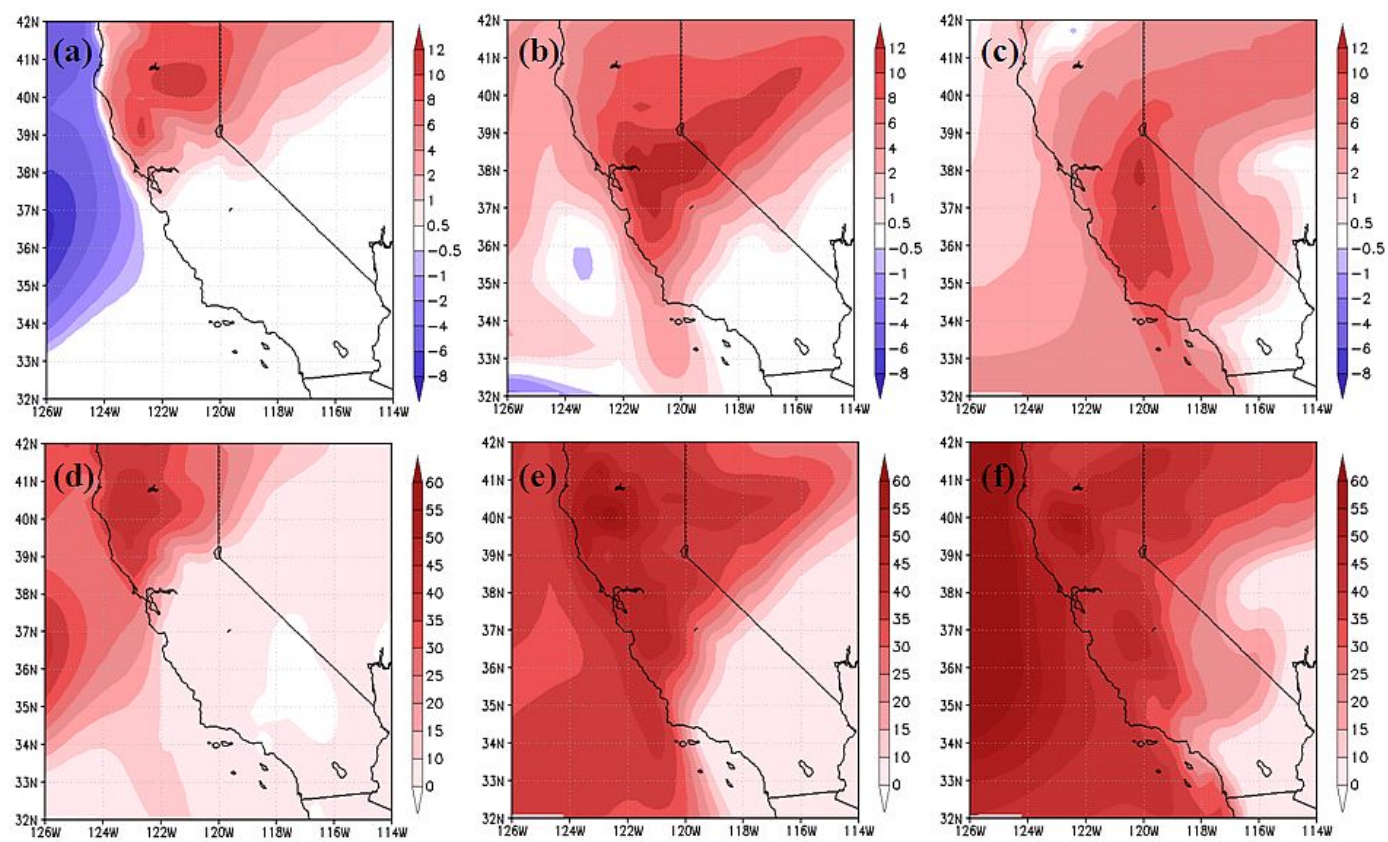

Fig. 15. Surface $\mathrm{O}_{3}(\mathbf{a}-\mathbf{c})$ and $\mathrm{CO}(\mathbf{d}-\mathbf{f})$ difference (Base case - Obs case) over California from $60 \mathrm{~km}$ model simulations at 18:00 UTC on 22 June (a; d), 23 (b; e) and 24 (c; f).
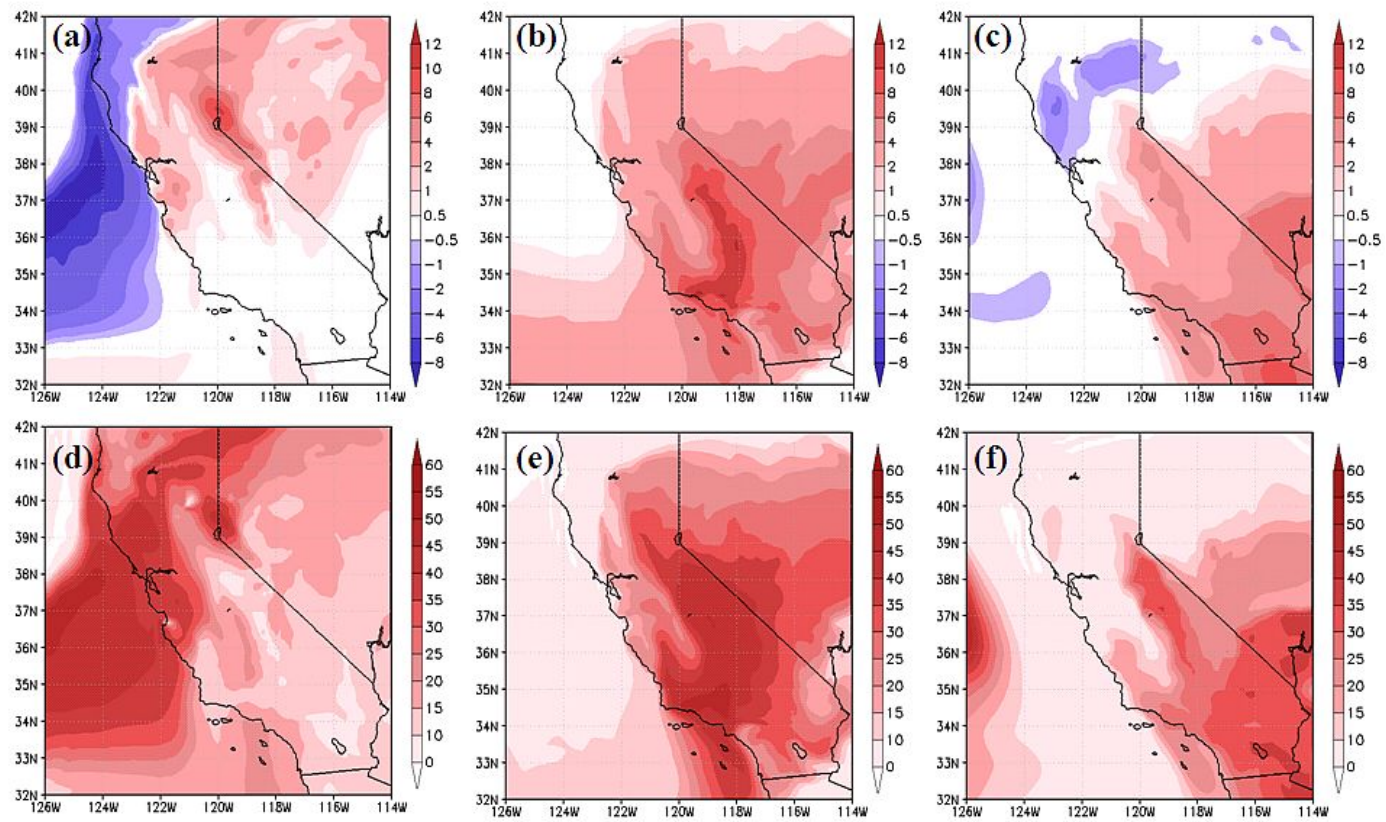

Fig. 16. Surface $\mathrm{O}_{3}(\mathbf{a}-\mathbf{c})$ and $\mathrm{CO}(\mathbf{d}-\mathbf{f})$ difference (Base case - Obs case) over California from $12 \mathrm{~km}$ model simulations at 18:00 UTC on 22 June $(a ; d), 23$ (b; e) and 24 (c; f).

California in the $60 \mathrm{~km}$ Obs case. The effects of the western LBC were first felt over northern California and then were transported to the south and the east in the next $24-48 \mathrm{~h}$.

The impact of the observational-based western LBC on the $12 \mathrm{~km}$ predictions is shown in Fig. 16. Ozone changes on 22 June are below $5 \mathrm{ppb}$ all over California, except along the border of California and Nevada. The impacts in the $12 \mathrm{~km}$ case traveled from north to south and moved out of the study domain after 24 June. These smaller impacts in the $12 \mathrm{~km}$ case compared to the $60 \mathrm{~km}$ case reflects the fact that the base $12 \mathrm{~km}$ simulation did not show as high a bias in northern California as did the $60 \mathrm{~km}$ simulation. The differences in 

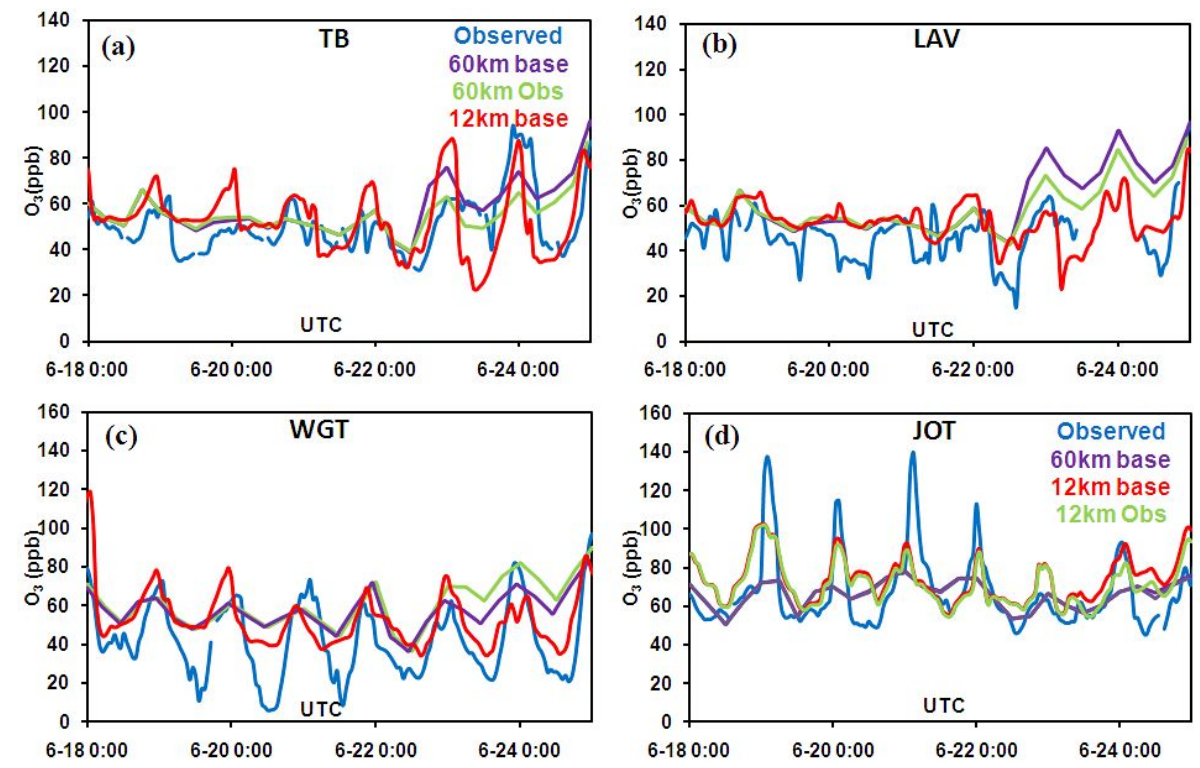

Fig. 17. Observed $\mathrm{O}_{3}$ time series in comparison with model simulations at (a) TB (b) LAV (c) WGT and (d) JOT during the flight week. Noticeable differences between the Obs case and base case results $(60 \mathrm{~km}(\mathrm{a}-\mathrm{c}) ; 12 \mathrm{~km}(\mathrm{~d}))$ were shown.

spatial patterns reflect the difference in meteorological fields at these resolutions, which can be implied along with the similar trend of changes in $\mathrm{CO}$ at corresponded times (Figs. 15 and $16 \mathrm{~d}-\mathrm{f}$ ). The $12 \mathrm{~km}$ wind fields better captured the detailed inland air movements and in-valley circulations. This is best seen in the fact that the changes in the $60 \mathrm{~km}$ Obs case mostly happened in northern California and in limited areas of central and southern California. In contrast, significant changes in $\mathrm{O}_{3}$ for the $12 \mathrm{~km}$ Obs case occurred over both northern and southern California.

To quantify the improvement in model simulations when using the observational-based western LBC, modeled and observed $\mathrm{O}_{3}$ time series plots for four surface sites are shown in Fig. 17. For the three sites located in northern California (Fig. 17a-c), the $60 \mathrm{~km}$ base case generally over-predicted $\mathrm{O}_{3}$ on 22 and 23 June. The Obs case reduced the overprediction. A detailed comparison of maximum, minimum and average $\mathrm{O}_{3}$ concentrations between model simulations and observations is summarized in Table $3 \mathrm{a}$ on 22 and 23 June. The $\mathrm{O}_{3}$ concentrations from the $60 \mathrm{~km}$ Obs case were closer to observations except that it missed the peak value at WGT on 23 June. In contrast, at the JOT site in southern California, there was no change of $\mathrm{O}_{3}$ after replacing western LBC with observations in $60 \mathrm{~km}$ during the same period (not shown). No significant differences were observed between $12 \mathrm{~km}$ base and Obs cases at the three northern California sites (not shown), but at the JOT site some small changes were seen (Fig. 17d). As Table 3b shows, maximum, average and minimum values of simulated $\mathrm{O}_{3}$ in $12 \mathrm{~km}$ Obs case decreased and its average and minimum $\mathrm{O}_{3}$ better captured the observations. The $\mathrm{O}_{3}$ decrease was larger after 23 June, due to the transport within the Central Valley as discussed previously. Table $3 \mathrm{a}$ and $\mathrm{b}$ show that $\mathrm{R}$-squares between observed and modeled surface $\mathrm{O}_{3}$ during 22-24 June were also improved at the surface sites in Obs cases, except for a slight decrease at TB site.

\subsubsection{Model performance improvement along flight path}

The improvement of $\mathrm{O}_{3}$ along the 22 and 24 June DC- 8 flights paths was also evaluated. To quantify the reduction of model biases, at all locations below $1000 \mathrm{~m}$ above ground, we define the Sensitivity Index (SI) in Eq. (2)

Sensitivity Index $\%=$

$$
\frac{\mid \mathrm{O}_{3} \text { in Obs case }- \text { Observed } \mathrm{O}_{3} \mid}{\mid \mathrm{O}_{3} \text { in Obs case }-\mathrm{O}_{3} \text { in base case } \mid} \cdot 100 \%
$$

This ratio of model bias can quantify the extent of model improvement by using the observational-based western LBC. $\mathrm{O}_{3}$ predictions were improved in Obs cases at locations with SI below $100 \%$. We also define cumulative sensitive data points, as well as the cumulative ratio in (3) and (4). Both of them are functions of SI.

Cumulative sensitive data points $(\mathrm{SI})=$ number of data points $<$ SI

Cumulative ratio $(\mathrm{SI})=\frac{\text { number of data points }<\mathrm{SI}}{\text { all data points }}$

Figure 18 shows that $60 \%$ and $70 \%$ of data points were improved in the $60 \mathrm{~km}$ and $12 \mathrm{~km}$ Obs cases. Furthermore, $26 \%$ and $17 \%$ of all data points in $60 \mathrm{~km}$ and $12 \mathrm{~km}$ cases, 
Table 3a. Comparisons between observed and modeled $\mathrm{O}_{3}$ at three northern California sites, better model simulations are in bold (OBSobservations).

\begin{tabular}{|c|c|c|c|c|c|c|c|c|c|c|}
\hline & & \multicolumn{3}{|c|}{$\mathrm{TB}$} & \multicolumn{3}{|c|}{ LAV } & \multicolumn{3}{|c|}{ WGT } \\
\hline & & OBS & $\begin{array}{l}60 \mathrm{~km} \\
\text { base }\end{array}$ & $\begin{array}{l}60 \mathrm{~km} \\
\text { Obs. }\end{array}$ & OBS & $\begin{array}{l}60 \mathrm{~km} \\
\text { base }\end{array}$ & $\begin{array}{l}60 \mathrm{k} \mathrm{m} \\
\text { Obs. }\end{array}$ & OBS & $\begin{array}{l}60 \mathrm{~km} \\
\text { base }\end{array}$ & $\begin{array}{l}60 \mathrm{~km} \\
\text { Obs. }\end{array}$ \\
\hline \multirow{3}{*}{$06 / 22$} & Max. & 57.0 & 57.1 & $\mathbf{5 7 . 0}$ & 58.0 & 58.8 & 58.6 & 51.7 & 72.0 & 67.0 \\
\hline & Mean & 42.8 & 48.7 & 48.2 & 39.9 & 51.1 & 50.5 & 34.6 & 51.2 & 49.4 \\
\hline & Min. & 31.0 & 38.9 & 38.0 & 15.0 & 43.1 & 42.9 & 22.4 & 36.3 & 36.2 \\
\hline \multirow[t]{3}{*}{$06 / 23$} & Max. & 62.0 & 75.8 & 63.1 & 64.0 & 85.0 & 73.0 & 82.1 & 80.7 & 70.9 \\
\hline & Mean & 53.9 & 64.7 & 54.7 & 53.3 & 75.3 & 64.6 & 44.0 & 70.4 & 59.5 \\
\hline & Min. & 34. & 52.2 & 49.3 & 40.0 & 62.0 & 54.6 & 21.8 & 62.4 & 50.6 \\
\hline $06 / 22-06 / 24$ & RSQ (OBS:Model) & & 0.35 & 0.31 & & 0.35 & 0.37 & & 0.39 & 0.44 \\
\hline
\end{tabular}

Table 3b. Comparisons between observed and modeled $\mathrm{O}_{3}$ at the southern California site JOT, better model simulations are in bold (OBSobservations).

\begin{tabular}{lllll}
\hline & & \multicolumn{3}{c}{ JOT } \\
& & OBS & $12 \mathrm{~km}$ base & $12 \mathrm{~km}$ Obs. \\
\hline $\mathbf{0 6 / 2 2}$ & Max. & 113.0 & $\mathbf{8 9 . 8}$ & 88.1 \\
& Mean & 64.3 & 68.3 & $\mathbf{6 7 . 8}$ \\
& Min. & 46.0 & 58.6 & $\mathbf{5 8 . 4}$ \\
$\mathbf{0 6 / 2 3}$ & Max. & 87.0 & $\mathbf{8 3 . 7}$ & 79.3 \\
& Mean & 59.1 & 67.8 & $\mathbf{6 3 . 3}$ \\
& Min. & 51.0 & 56.1 & $\mathbf{5 4 . 8}$ \\
$\mathbf{0 6 / 2 4}$ & Max. & 93.0 & 101.0 & $\mathbf{9 4 . 7}$ \\
& Mean & 63.7 & 81.6 & $\mathbf{7 4 . 4}$ \\
& Min. & 45.0 & 71.0 & $\mathbf{6 5 . 3}$ \\
$\mathbf{0 6 / 2 2 - 0 6 - 2 4}$ & RSQ (OBS:Model) & & 0.40 & $\mathbf{0 . 4 4}$ \\
\hline
\end{tabular}

respectively, had SI values below $80 \%$. The model biases for these points were reduced by more than $20 \%$ when the observational-based LBC was used. These data points are colored by SI in Figs. 18b and 19c. They are mostly located in northern California, along the coast of southern California, and downwind areas of the Central Valley. The highest improvements (with $\mathrm{SI}<20 \%$ ) for the $60 \mathrm{~km}$ case were over northern California, and over southern California downwind of the Central Valley in the $12 \mathrm{~km}$ case. These improvements in $60 \mathrm{~km}$ and $12 \mathrm{~km}$ model performance along two flight paths on 22 and 24 June show some similarities to the improvement seen at the surface sites in response to the observational-based western LBC.

These results suggest that the added observations contributed appreciably to improving model predictions. Chemical data assimilation in global models holds the possibility of reducing uncertainties in LBC used in limited-area air quality models. However, the RAQMS first guess boundary conditions used are based on MLS and OMI data that contain low information content in the mid to lower troposphere. Additional information is available from current satellite instruments such as TES, however TES lacks the temporal and spatial coverage needed for LBCs. The measurements from aircraft contain high information content and the observationalbased LBC can highly improve regional model performance over downwind areas at lower troposphere. The challenge that remains is to improve our observing system in ways that it can provide the spatial and temporal information needed to improve model predictions of air quality. This should be a priority of our future observing systems.

\section{Summary and conclusions}

Tracer and full-chemistry versions of STEM model at three spatial scales were used to analyze the effects of transported background $\mathrm{O}_{3}$ from the eastern Pacific on California air quality during the ARCTAS-CARB experiment conducted in 

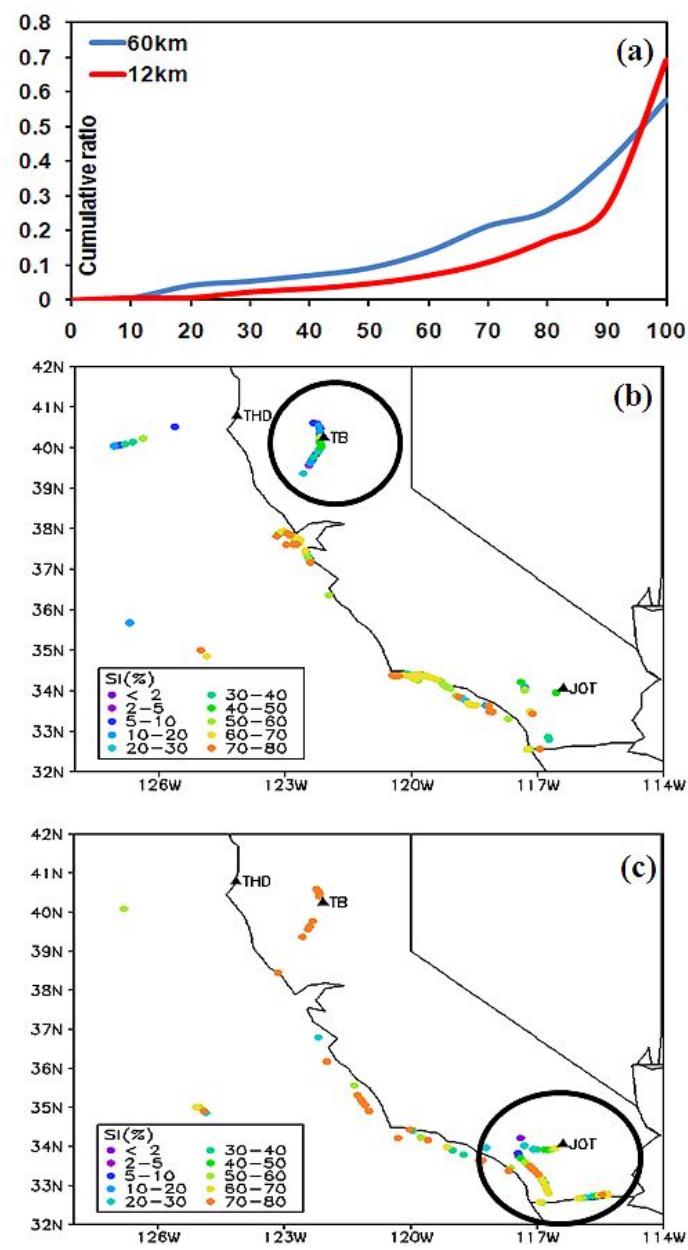

Fig. 18. (a) Cumulative ratios for $60 \mathrm{~km}$ and $12 \mathrm{~km}$ cases; Data points below $80 \% \mathrm{SI}$ in (b) $60 \mathrm{~km}$ and (c) $12 \mathrm{~km}$ cases along the 22 and 24 June flight tracks below $1000 \mathrm{~m}$.

June 2008. Two different spatial resolutions and a variety of lateral boundary conditions (LBC) were applied in the fullchemistry model simulations.

Tracer model and back trajectories indicated that during 21-24 June strong Asian inflows affected northern California. Based on the $12 \mathrm{~km}$ meteorological fields, we analyzed reconstructed $\mathrm{O}_{3}$ distributions along air-mass back trajectories originating at five California sites and correlated observed and modeled $\mathrm{O}_{3}$ between coastal THD and inland TB sites to study $\mathrm{O}_{3}$ transport patterns. During the entire ARCTAS-CARB study period $\mathrm{O}_{3}$ levels in the inflow air

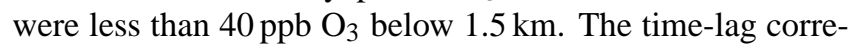
lations of $\mathrm{O}_{3}$ at this altitude with a surface site at TB showed maximum correlations of 0.3 and a transport time of less than $30 \mathrm{~h}$. Under Asia inflow conditions during 21-24 June the peak R-square value increased to approximate 0.7 , and the transport altitude was extended to around $3 \mathrm{~km}$ where 60 $80 \mathrm{ppb}$ of coastal $\mathrm{O}_{3}$ was observed.
We evaluated the sensitivity of modeled $\mathrm{O}_{3}$ to various treatments of the boundary conditions and showed that modeled $\mathrm{O}_{3}$ over downwind areas were highly sensitive to the western LBC during 21-24 June. The use of constant values failed to capture the varied $\mathrm{O}_{3}$ vertical structures over the eastern Pacific during this time period. We showed the results of using top and lateral boundary conditions downscaled from the RAQMS global model, but also showed that they can contain biases. Temporal averaging of these boundary conditions is shown to be one way to reduce such biases.

In addition to model-based real-time LBC, the measurements on the 22 June DC- 8 flight provided actual $\mathrm{O}_{3}$ vertical gradients over the ocean, which were used as LBC. Use of these observation-based LBC was shown to improve $\mathrm{O}_{3}$ predictions at four California inland surface sites and at altitudes below $1000 \mathrm{~m}$ along two DC-8 flight tracks. The extent of model improvement over different areas depended on base case performance, meteorology fields and the discrepancies of model-based western LBC from the flight observations.

We conclude from this study that:

1. The pollutant transport patterns from oceanic background and their effects on California air quality (or other similar regions) depend on the vertical structures over the eastern Pacific and meteorological conditions. Long-range transport of Asian inflows can change the pollutant profiles over the eastern Pacific during summertime significantly. Capturing this variability in the observations is important and challenging as information is needed above the surface.

2. Accurate real-time LBC for long-live species together with high quality meteorology fields improve model predictions in areas where the background pollutants are transported aloft as well as their downwind regions. The assimilation with OMI and MLS data into RAQMS together with the assimilation of in-situ measurements in to STEM LBCs improved the model performance. Improvements in our observing systems that provide information on the three-dimensional nature of pollutant distributions are needed to improve our capability to predict pollution levels and to better quantify the influence of these Asian inflows on the US west coast air quality.

Acknowledgements. We would like to thank the ARCTAS science team. This work was supported by a NASA award (NNX08AH56G). The authors would also like to acknowledge NOAA, the US EPA and CARB for support of the sounding and ground measurements. The views, opinions, and findings contained in this report are those of the author(s) and should not be construed as an official NOAA or US Government position, policy, or decision.

Edited by: A. Stohl 


\section{References}

Adhikary, B., Carmichael, G. R., Kulkarni, S., Wei, C., Tang, Y., D’Allura, A., Mena-Carrasco, M., Streets, D. G., Zhang, Q., Pierce, R. B., Al-Saadi, J. A., Emmons, L. K., Pfister, G. G., Avery, M. A., Barrick, J. D., Blake, D. R., Brune, W. H., Cohen, R. C., Dibb, J. E., Fried, A., Heikes, B. G., Huey, L. G., O'Sullivan, D. W., Sachse, G. W., Shetter, R. E., Singh, H. B., Campos, T. L., Cantrell, C. A., Flocke, F. M., Dunlea, E. J., Jimenez, J. L., Weinheimer, A. J., Crounse, J. D., Wennberg, P. O., Schauer, J. J., Stone, E. A., Jaffe, D. A., and Reidmiller, D. R.: A regional scale modeling analysis of aerosol and trace gas distributions over the eastern Pacific during the INTEX-B field campaign, Atmos. Chem. Phys., 10, 2091-2115, doi:10.5194/acp10-2091-2010, 2010.

Akima, H.: A New Method of Interpolation and Smooth Curve Fitting Based on Local Procedures, J. ACM, 17(4), 589-602, 1970.

Carter, W. P. L.: Documentation of the SAPRC-99 chemical mechanism for VOC Reactivity Assessment, final report to California Air Resources Board, Contract No. 92-329 and 95-308, 2000.

Carmichael, G. R., Tang, Y., Kurata, G., Uno, I., Streets, D., Woo, J.-H., Huang, H., Yienger, J., Lefer, B., Shetter, R., Blake, D., Atlas, E., Fried, A., Apel, E., Eisele, F., Cantrell, C., Avery, M., Barrick, J., Sachse, G., Brune, W., Sandholm, S., Kondo, Y., Singh, H., Talbot, R., Bandy, A., Thorton, D., Clarke, A., and Heikes, B.: Regional-scale chemical transport modeling in support of the analysis of observations obtained during the TRACE-P experiment, J. Geophys. Res., 108(D21), 8823, doi:10.1029/2002JD003117, 2003.

Chen, F. and Dudhia, J.: Coupling an advanced land-surface/ hydrology model with the Penn State/ NCAR MM5 modeling system. Part I: Model description and implementation, Mon. Weather Rev., 129, 569-585, 2001.

Chou, M.-D. and Suarez, M. J.: An efficient thermal infrared radiation parameterization for use in general circulation models, NASA Tech. Memo, 104606, 3, 85, 1994.

Cooper, O. R., Parrish, D. D., Stohl, A., Trainer, M., Nedelec, P., Thouret, V., Cammas, J. P., Oltmans, S. J., Johnson, B. J., Tarasick, D., Leblanc, T., McDermid, I. S., Jaffe, D., Gao, R., Stith, J., Ryerson, T., Aikin, K., Campos, T., Weinheimer, A., and Avery, M. A.: Increasing springtime ozone mixing ratios in the free troposphere over western North America, Nature, 463, 344-348, doi:10.1038/nature08708, 2010.

Davies, D. K., Ilavajhala, S., Wong, M. M., and Justice, C. O.: Fire Information for Resource Management System: Archiving and Distributing MODIS Active Fire Data, IEEE T. Geosci. Remote, 47(1), 72-79 2009.

Dillon, M. B., Lamanna, M. S., Schade, G. W., Goldstein, A. H., and Cohen, R. C.: Chemical evolution of the Sacramento urban plume: Transport and oxidation, J. Geophys. Res., 107(D5), 4045, doi:10.1029/2001JD000969, 2002.

D’Allura, A., Kulkarni, S., Carmichael, G. R., Finardi, S., Adhikary, B., Wei, C., Streets, D. G., Zhang, Q., Pierce, R. B., AlSaadi, J. A., Diskin, G., and Wennberg, P. O.: Meteorological and air quality forecasting products during the 2008 ARCTAS field campaign, Atmos. Environ., in review, 2010.

Fiore, A., Jacob, D. J., Liu, H., Yantosca, R. M., Fairlie, T. D., and Li, Q.: Variability in surface ozone background over the United States: Implications for air quality policy, J. Geophys. Res., 108(D24), 4787, doi:10.1029/2003JD003855, 2003.
Fuelberg, H. E., Harrigan, D. L., and Sessions, W.: A meteorological overview of the ARCTAS 2008 mission, Atmos. Chem. Phys., 10, 817-842, doi:10.5194/acp-10-817-2010, 2010.

Giglio, L., Descloitres, J., Justice, C. O., and Kaufman, Y. J.: An Enhanced Contextual Fire Detection Algorithm for MODIS, Remote Sens. Environ., 87, 273-282, 2003.

Hong, S.-Y., Dudhia, J., and Chen, S.-H.: A Revised Approach to Ice Microphysical Processes for the Bulk Parameterization of Clouds and Precipitation, Mon. Weather Rev., 132, 103-120, 2004.

Jacob, D. J., Crawford, J. H., Maring, H., Clarke, A. D., Dibb, J. E., Emmons, L. K., Ferrare, R. A., Hostetler, C. A., Russell, P. B., Singh, H. B., Thompson, A. M., Shaw, G. E., McCauley, E., Pederson, J. R., and Fisher, J. A.: The Arctic Research of the Composition of the Troposphere from Aircraft and Satellites (ARCTAS) mission: design, execution, and first results, Atmos. Chem. Phys., 10, 5191-5212, doi:10.5194/acp-10-5191-2010, 2010.

Jaffe, D. A., Parrish, D., Goldstein, A., Price H., and Harris, J.: Increasing background ozone during spring on the west coast of North America, Geophys. Res. Lett., 30(12), 1613, doi:10.1029/2003GL017024, 2003.

Janjic, Z. I.: Comments on "Development and Evaluation of a Convection Scheme for Use in Climate Models", J. Atmos. Sci., 57, p. 3686, 2000.

Janjic, Z. I.: Nonsingular Implementation of the Mellor-Yamada Level 2.5 Scheme in the NCEP Meso model, NCEP Office Note, No. 437, 61, 2002.

Kim, Y. P. and Seinfeld, J. H.: Atmospheric Gas-Aerosol Equilibrium: III. Thermodynamics of Crustal Elements $\mathrm{Ca}^{2+}, \mathrm{K}^{+}$, and $\mathrm{Mg}^{2+}$, Aerosol Sci. Technol., 22(1), 93-110, 1995.

Kurata, G., Carmichael, G. R., Streets, D. G., Kitada, T., Tang, Y., Woo, J. H., and Thongboonchoo, N.: Relationships between emission sources and air mass characteristics in East Asia during the TRACE-P period, Atmos. Environ., 38(40), 6977-6987, 2004.

Lathière, J., Hauglustaine, D. A., Friend, A. D., De NobletDucoudré, N., Viovy, N., and Folberth, G. A.: Impact of climate variability and land use changes on global biogenic volatile organic compound emissions, Atmos. Chem. Phys., 6, 2129-2146, doi:10.5194/acp-6-2129-2006, 2006.

Law, K.: Atmospheric chemistry: More ozone over North America, Nature, 463, 307-308, 2010.

Lefohn, A. S., Oltmans, S. J., Dann, T., and Singh, H. B.: Presentday variability of background ozone in the lower troposphere, J. Geophys. Res., 106(D9), 9945-9958, 2001.

Lin, C.-Y. C., Jacob, D. J., Munger, J. W., and Fiore, A. M.: Increasing background ozone in surface air over the United States, Geophys. Res. Lett., 27(21), 3465-3468, 2001.

Madronich, S., Flocke, S., Zeng, J., Petropavlovskikh, I., and Lee-Taylor, J.: The Tropospheric Ultra-violet Visible (TUV) model Manual, available online at: http://www.acd.ucar.edu/ TUV, 2002.

McKendry, I. G.: Background concentrations of $\mathrm{PM}_{2.5}$ and ozone in British Columbia, Canada, , available online at: http://www.bcairquality.ca/reports/pdfs/background_pm25_ ozone.pdf (last access: 2009), 2006.

Mesingera, F., DiMego, G., Kalnay, E., Mitchell, K., Shafran, P. C., Ebisuzaki, W., Jovic, D., Woollen, J., Rogers, E., Berbery, E. H., Ek, M. B., Fan, Y., Grumbine, R., Higgins, W., Li, H., 
Lin, Y., Manikin, G., Parrish, D., and Shi, W.: North American Regional Reanalysis, B. Am. Meteor. Soc., 87(3), 343-360, doi:10.1175/BAMS-87-3-343, 2006.

Mlawer, E. J., Taubman, S. J., Brown, P. D., Iacono, M. J., and Clough, S. A.: Radiative transfer for inhomogeneous atmosphere: RRTM, a validated correlated-k model for the longwave, J. Geophys. Res., 102(D14), 16663-16682, 1997.

Monin, A. S. and Obukhov, A. M.: Basic laws of turbulent mixing in the surface layer of the atmosphere. Contrib. Geophys. Inst. Acad. Sci., USSR, (151), 163-187, 1954 (in Russian).

NAS report: global sources of local pollution-An Assessment of Long-Range Transport of Key Air Pollutants to and from the United States, 35-66, available online at: http://books.nap.edu/ openbook.php?record_id=12743\\&page=35, 2010.

NASA: OMI $\mathrm{O}_{3}$ column data: ftp://toms.gsfc.nasa.gov/pub/omi/ data/ozone/Y2008/, 2009.

NCEP/NOAA: Real-time, global, sea surface temperature (RTG_SST) analysis data source, available online at: ftp://polar.ncep.noaa.gov/pub/history/sst/, 2008.

Nolle, M., Ellul, R., Gusten, H., and Heinrich, G.: Long-term background ozone and carbon monoxide measurements on the Maltese Islands, Proceedings of the European Symposium on the Physico Chemical behaviour of Atmospheric Pollutants, Turin, Italy, September 2001.

Oltmans, S. J., Lefohn, A. S., Harris, J. M., and Shadwick, D. S.: Background ozone levels of air entering the west coast of the U.S. and assessment of longer-term changes, Atmos. Environ., 42, 6020-6038, 2008.

Parrish, D. D., Millet, D. B., and Goldstein, A. H.: Increasing ozone in marine boundary layer inflow at the west coasts of North America and Europe, Atmos. Chem. Phys., 9, 1303-1323, doi:10.5194/acp-9-1303-2009, 2009.

Parrish, D. D., Aikin, K. C., Oltmans, S. J., Johnson, B. J., Ives, M., and Sweeny, C.: Impact of transported background ozone inflow on summertime air quality in a California ozone exceedance area, Atmos. Chem. Phys. Discuss., 10, 16231-16276, doi:10.5194/acpd-10-16231-2010, 2010.

Pierce, R. B., Schaack, T., Al-Saadi, J. A., Fairlie, T. D., Kittaka, C., Lingenfelser, G., Natarajan, M., Olson, J., Soja, A., Zapotocny, T., Lenzen, A., Stobie, J., Johnson, D., Avery, M. A., Sachse, G. W., Thompson, A., Cohen, R., Dibb, J. E., Crawford, J., Rault, D., Martin, R., Szykman, J., and Fishman, J.: Chemical data assimilation estimates of continental U.S. ozone and nitrogen budgets during the Intercontinental Chemical Transport Experiment-North America, J. Geophys. Res., 112, D12S21, doi:10.1029/2006JD007722, 2007.
Skamarock, W. C., Klemp, J. B., Dudhia, J., Gill, D., Barker, D. M., Wang, W., and Powers, J. G.: A Description of the Advanced Research WRF Version 2, available online at: www.mmm.ucar. edu/wrf/users/docs/arw_v2.pdf, 2007.

Tang, Y., Carmichael, G. R., Horowitz, L. W., Uno, I., Woo, J.H., Streets, D. G., Dabdub, D., Kurata, G., Sandu, A., Allan, J., Atlas, E., Flocke, F., Huey, L. G., Jakoubek, R. O., Millet, D. B., Quinn, P. K., Roberts, J. M., Worsnop, D. R., Goldstein, A., Donnelly, S., Schauffler, S., Stroud, V., Johnson, K., Avery, M. A., Singh, H. B., and Apel, E. C.: Multi-scale simulations of tropospheric chemistry in the eastern Pacific and on the U.S. West Coast during spring 2002, J. Geophys. Res., 109, D23S11, doi:10.1029/2004JD004513, 2004a.

Tang, Y., Carmichael, G. R., Kurata, G., Uno, I., Weber, R. J., Song, C.-H., Guttikunda, S. K., Woo, J.-H., Streets, D. G., Wei, C., Clarke, A. D., Huebert, B., and Anderson, T. L.: Impacts of dust on regional tropospheric chemistry during the ACE-Asia experiment: A model study with observations, J. Geophys. Res., 109, D19S21, doi:10.1029/2003JD003806, 2004b.

Tang, Y. H., Carmichael, G. R., Thongboonchoo, N., Chai, T. F., Horowitz, L. W., Pierce, R. B., Al-Saadi, J. A., Pfister, G., Vukovich, J. M., Avery, M. A., Sachse, G. W., Ryerson, T. B., Holloway, J. S., Atlas, E. L., Flocke, F. M., Weber, R. J., Huey, L. G., Dibb, J. E., Streets, D. G., and Brune, W. H.: Influence of lateral and top boundary conditions on regional air quality prediction: A multi-scale study coupling regional and global chemical transport models, J. Geophys. Res.-Atmos., 112, D10S18, doi:10.1029/2006JD007515, 2007.

Tang, Y., Lee, P., Tsidulko, M., Huang, H., McQueen, J. T., DiMego, G. J., Emmons, L. K. , Pierce, R. B, Thompson, A. M., Lin, H, Kang, D., Tong, D., Yu, S., Mathur, R., Pleim, J. E., Otte, T. L., Pouliot, G., Young, J. O., Schere, K. L., Davidson, P. M., and Stajner, I.: The impact of chemical lateral boundary conditions on CMAQ predictions of tropospheric ozone over the continental United States, Environ. Fluid Mech., 9, 43-58, doi:10.1007/s10652-008-9092-5, 2009.

U.S. Environmental Protection Agency: Air quality criteria for ozone and related photochemical oxidants (final), Volumes I, II, and III, EPA 600/R-05/004aF-cF, 2006.

Vingarzan, R.: A review of surface ozone background levels and trends, Atmos. Environ., 38(21), 3431-3442, doi:10.1016/j.atmosenv.2004.03.030, 2004.

WRF/Chem Version 3.1 User's Guide, available online at: http:// ruc.noaa.gov/wrf/WG11/Users_guide.pdf, 2009. 